
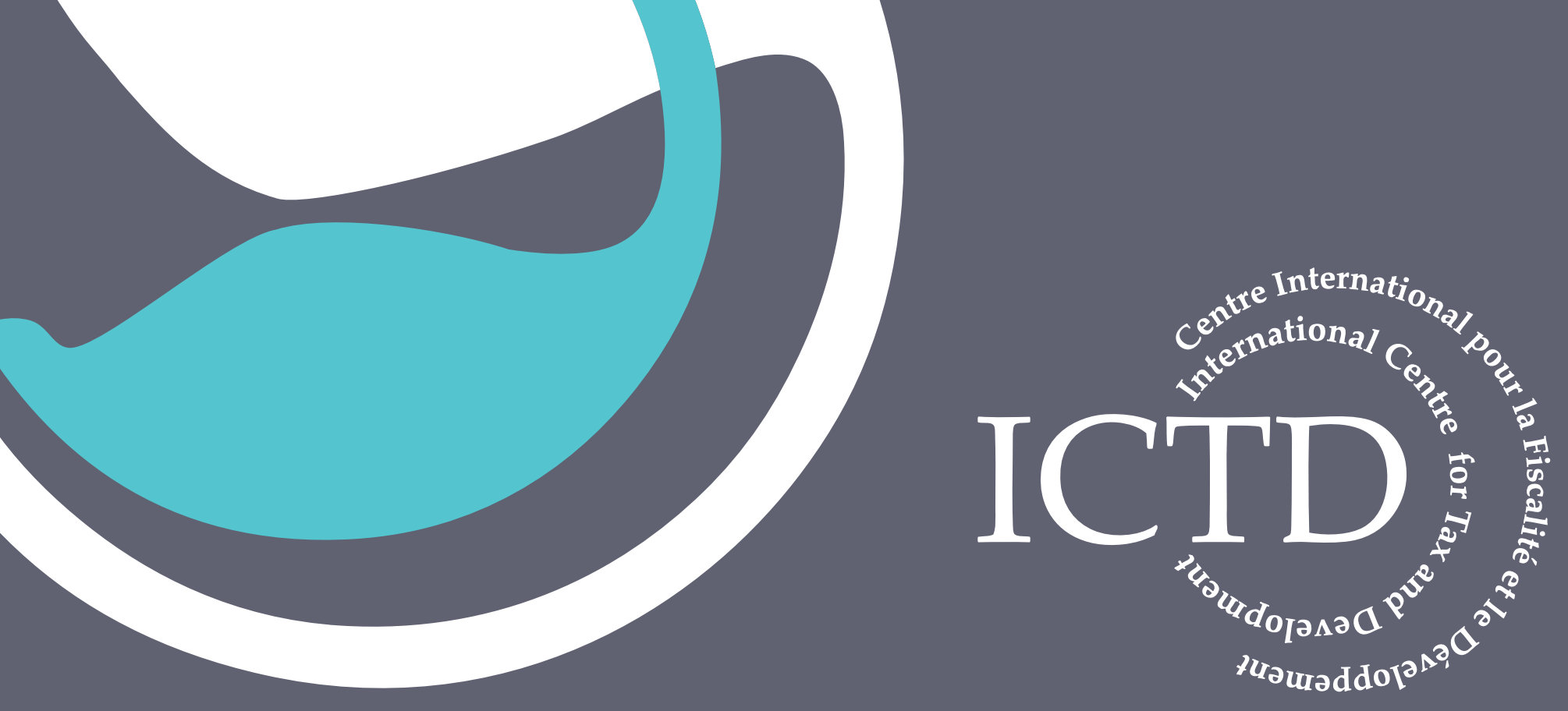

Working Paper 50

\title{
A Review of Uganda's Tax Treaties and Recommendations for Astion
}

Martin Hearson and Jalia Kangave

March 2016 
ICTD Working Paper 50

\section{A Review of Uganda's Tax Treaties and Recommendations for Action}

Martin Hearson and Jalia Kangave

March 2016 




A catalogue record for this publication is available from the British Library.

All rights reserved. Reproduction, copy, transmission, or translation of any part of this publication may be made only under the following conditions:

- with the prior permission of the publisher; or

- with a licence from the Copyright Licensing Agency Ltd., 90 Tottenham Court Road, London W1P 9HE, UK,

or from another national licensing agency; or

- under the terms set out below.

This publication is copyright, but may be reproduced by any method without fee for teaching or nonprofit purposes, but not for resale. Formal permission is required for all such uses, but normally will be granted immediately. For copying in any other circumstances, or for reuse in other publications, or for translation or adaptation, prior written permission must be obtained from the publisher and a fee may be payable.

\section{Available from:}

The International Centre for Tax and Development

at the Institute of Development Studies,

Brighton BN1 9RE, UK

Tel: +44 (0) 1273606261 Fax: +44 (0) 1273621202

E-mail: info@ictd.ac.uk

Web: www.ictd/en/publications

IDS is a charitable company limited by guarantee and registered in England (No. 877338) 


\title{
A Review of Uganda's Tax Treaties and Recommendations for Action
}

\author{
Martin Hearson and Jalia Kangave
}

\section{Summary}

In June 2014, Uganda announced the temporary cessation of bilateral tax treaty negotiations, and a review of its policy towards such treaties. The main effect of tax treaties is to divide up the 'rights' to tax cross-border investment between the state parties, which reduces the possibility that businesses will incur double taxation; in doing so, it places significant curbs on the ability of capital-importing countries, such as Uganda, to tax foreign investors.

Uganda's review follows decisions by developing countries as diverse as Argentina, Mongolia, Rwanda and Zambia to cancel or renegotiate some of their historical tax treaties. These countries, together with some independent commentators, international and nongovernmental organisations, have questioned whether the benefits of tax treaties for developing countries outweigh their costs. In Uganda, as elsewhere, tax treaties have always been surrounded by an investment promotion discourse in political debate, yet there is little convincing evidence that they have had a positive effect on investment flows into low-income countries. In contrast, there are some clear aspects of Uganda's treaties, such as definitions of 'permanent establishment' and rules concerning the taxation of capital gains, which cost Uganda significant revenue and are vulnerable to abusive tax planning. A key problem is that Uganda's negotiating position has been based on the UN model treaty, which embodies a compromise position, rather than an ideal one to be horse-traded during negotiations. The recent East African Community (EAC) and Common Market for Eastern and Southern Africa (COMESA) model treaties also represent compromise positions.

This paper uses a comparative analysis of treaties signed by Uganda and other neighbouring countries, combined with interviews conducted with government officials and private sector tax advisers, to assess whether Uganda's network of tax treaties is fit for purpose, and to recommend how it could be improved through the policy review.

Keywords: capital gains tax; corporation tax; double taxation agreement; sub-Saharan Africa; tax treaty; treaty shopping; Uganda; withholding tax.

Martin Hearson is a doctoral researcher at the London School of Economics, where he focuses on the political economy of tax treaty negotiations. He has worked with a wide range of non-governmental organisations on tax and development research, and writes a blog on international taxation at <martinhearson. wordpress.com>.

Jalia Kangave is a Research Fellow at the Institute of Development Studies, University of Sussex, focussing primarily on taxation and governance at IDS's International Centre for Tax and Development (ICTD). Before joining IDS, she was a Programme Lead/External Researcher on the project 'Boosting Revenue Collections from High Net Worth Individuals in Uganda' for ICTD and the Uganda Revenue Authority. She has served as Principal of the East African School of Taxation, and a Collaborative Researcher for UNRISD. 


\section{Contents}

Summary 3

Acknowledgements

Acronyms $\quad 5$

Introduction 6

$1 \quad$ Tax treaties: a brief survey of the literature $\quad 8$

2 Unconvincing explanations for the development of Uganda's tax treaty network

2.1 Investment promotion and 'tax sparing' 9

2.2 Relieving double taxation 10

2.3 Treaties as tax incentives 11

$\begin{array}{lll}2.4 & \text { Fiscal cooperation } & 13\end{array}$

$3 \quad$ Problems with the content of Uganda's existing treaties 14

3.1 Uganda's treaty network is much less favourable that the UN model treaty 15

3.1.1 Withholding tax rates 16

3.1.2 The definition of permanent establishment 16

3.1.3 Capital gains 17

3.2 There is evidence of significant revenue loss due to preventable treaty shopping

$4 \quad$ Problems with model treaties 20

4.1 Uganda and the UN model 20

4.2 Uganda and the OECD model 20

4.3 Uganda and the EAC model 21

4.4 Uganda and the COMESA model 22

4.5 Uganda needs an ambitious new model treaty 23

$5 \quad$ A holistic approach to tax treaty policy 23

5.1 Treaty gains may be eroded by tax incentives contained in foreign
investments contracts, such as production sharing arrangements

5.2 Interaction between BITs and the loss of domestic tax revenue 24

6.3 In some places, Uganda's domestic law is weaker than international
model treaties and existing tax treaties

$6 \quad$ Conclusion and recommendations 26

Annex: Additional tables $\quad 29$

References $\quad 33$

Tables

Table 1

Table 2

Table 3

Table 4

Table 5

Investment stock in Uganda, 2012

12

Fiscal cooperation provisions in Uganda's tax treaties 13

Selection provisions of Uganda's tax treaties 15

Estimated revenue foregone due to reduced WHTs in treaties 16

Examples of specific anti-abuse rules from the UN model in Uganda's tax treaties 


\section{Acknowledgements}

The authors are grateful to Tax Justice Network Africa for funding fieldwork in Kampala that contributed to this report (and which also led to the report Tax Treaties in Sub-Saharan Africa: a critical review), to SEATINI and ActionAid Uganda for assistance arranging interviews, to the interviewees who gave time and insight to this research, and to two anonymous reviewers for helpful comments. Any remaining errors are the authors' own.

\section{Acronyms}

$\begin{array}{ll}\text { ATAF } & \text { African Tax Administration Forum } \\ \text { BEPS } & \text { Base Erosion and Profit Shifting } \\ \text { BIT } & \text { Bilateral Investment Treaty } \\ \text { COMESA } & \text { Common Market for Eastern and Southern Africa } \\ \text { DTA } & \text { Double Taxation Agreement (tax treaty) } \\ \text { EAC } & \text { East African Community } \\ \text { FDI } & \text { Foreign Direct Investment } \\ \text { GBC } & \text { Global Business Company } \\ \text { LOB } & \text { Limitation of Benefits } \\ \text { MAP } & \text { Mutual Agreement Procedure } \\ \text { MFN } & \text { Most-Favoured Nation } \\ \text { MoFPED } & \text { Ministry of Finance, Planning and Economic Development } \\ \text { OECD } & \text { Organisation for Economic Cooperation and Development } \\ \text { PE } & \text { Permanent Establishment } \\ \text { PSA } & \text { Production Sharing Agreement } \\ \text { SADC } & \text { Southern African Development Community } \\ \text { TIEA } & \text { Tax Information Exchange Agreement } \\ \text { UIA } & \text { Ugandan Investment Authority } \\ \text { UN } & \text { United Nations } \\ \text { URA } & \text { Uganda Revenue Authority } \\ \text { WHT } & \text { Withholding Tax }\end{array}$




\section{Introduction}

At the beginning of 2014, there were approximately 300 bilateral tax treaties in force in subSaharan African countries. Commonly framed as investment promotion tools, tax treaties are agreements through which state parties voluntarily agree to restrictions on their ability to tax economic activity that spans both countries. In particular, they prevent capital-importing countries from taxing inward investment in certain circumstances: for example, if the investor's physical presence does not meet a certain threshold (known as permanent establishment), or if the income is of an excluded type, such as capital gains from sales of shares, or profits from shipping operations. Tax treaties also specify the rates at which capital-importing countries can levy withholding taxes on payments made to companies in the treaty partner, in particular on dividends, interest, royalties and technical service fees. All these provisions of tax treaties override domestic law in the capital-importing country, not just at the date of signature, but as long as the treaty remains in force. Because they are net capital importers in the case of most tax treaties they sign, developing countries usually bear most of these costs when they conclude tax treaties.

The original logic behind these restrictions was that they removed onerous double taxation on cross-border investors, which resulted from the two countries' competing claims to taxing their income, and depressed the level of investment. The question of whether or not the sacrifices made by developing countries when they sign tax treaties are justified by the benefits that they receive from any inward investment that might result, has been debated for as long as they have negotiated tax treaties (see, e.g. Irish 1974). There are two main concerns: the deliberate tax cost resulting from the restrictions on the developing country's taxing rights, and the unintended tax cost resulting from the abuse of certain tax treaties in aggressive tax planning schemes. ${ }^{1}$

The latter concern has come to the fore in recent years as policymakers, campaigners and international organisations have focused attention on tax planning by multinational companies. SOMO, a Dutch NGO, has argued that 'treaty shopping', which takes advantage of developing countries' treaties with the Netherlands, costs them significant revenue (McGauran 2013; Weyzig and van Dijk 2007). The IMF (2014a: 24) states that, for the same reason, developing countries 'would be well-advised to sign treaties only with considerable caution'. As part of its work to address treaty abuse, the OECD (2014a: 102) has produced guidance to 'make it easier for countries to justify their decisions not to enter into tax treaties with certain low or no-tax jurisdictions'. In Uganda, two local NGOs, SEATINI and ActionAid Uganda, have argued that the country's tax treaty network 'is one of the mechanisms used by companies to avoid paying taxes, leading to illicit financial flows and tax losses for Uganda' (SEATINI and ActionAid Uganda 2014).

This debate has also translated into changes to tax treaty networks. South Africa and Rwanda have successfully renegotiated their agreements with Mauritius. Argentina and Mongolia have cancelled or renegotiated several agreements with European countries. Zambia has renegotiated its treaties with Ireland and the Netherlands, and Malawi with the latter. Perhaps in response to the international debate and the threat of further cancellations, the Netherlands and Ireland have both also begun a process of review of their tax treaties with developing countries (Irish Ministry of Finance 2014; Netherlands Ministry of Finance 2013). 
In this context, Uganda's Ministry of Finance, Planning and Economic Development (MoFPED) has announced a review of its tax treaty network. ${ }^{2}$ MoFPED officials state that the review is motivated by a number of concerns. The lack of a politically derived policy to underpin negotiations is one. 'When I go to negotiate, all I have is my own judgement', according to one negotiator. 'We thought that cabinet should express itself'. ${ }^{3}$ Officials are also concerned that Uganda's tax treaties prevent it from taxing professionals providing technical services to its relatively young oil industry, and are questioning whether their as yet unratified treaty with China, which notoriously drives a hard bargain with developing countries (Li 2012), would curb Uganda's taxing rights too much.

With nine treaties in force, and several more pending ratification, Uganda can be described as a typical case. The median number of bilateral tax treaties signed by sub-Saharan countries is just four, but that rises to nine for former British colonies. ${ }^{4}$ For Uganda, as for the region, the largest share of these treaties is with Western Europe, although a growing number are being concluded between sub-Saharan countries, and with middle-income countries. A review of Uganda's treaties may therefore be instructive for many other countries in the region. As Uganda is a member of the EAC and COMESA, both of which have model tax treaties, the review could also identify areas in which these models could be strengthened to serve as more effective opening positions in negotiations.

The review presents an opportunity for Uganda to formulate a clear, evidence-based approach to tax treaties, beginning by asking questions that African countries seem rarely to have posed - or else to which they have forgotten the answers. What effect do Uganda's tax treaties have on investment flows and tax revenue? What are the costs and benefits of tax treaties with particular partners and containing particular provisions? How many taxing rights is it worth giving up in order to reach agreement with a potential treaty partner? What would be the consequence of cancelling a tax treaty? Above all, why does Uganda have tax treaties?

After a brief review of the general literature in Section 1, this paper evaluates Uganda's treaty network in four sections. Section 2 examines the development of Uganda's treaty network to date, using historical records, interviews and legal analysis to conclude that no compelling rationale has been articulated that justifies the fiscal costs in 2015. Section 3 examines those fiscal costs in more detail, comparing Uganda's treaties to the UN model tax treaty, which officials cite as Uganda's negotiating position, and examining how the treaties are open to abuse. In section 4, the model treaties to which Uganda is a party are examined, to illustrate that renegotiations are unlikely to generate significant improvements if a business-as-usual approach is maintained. Section 5 broadens the analysis to take into account domestic law and other legal instruments that interact with tax treaties. The paper concludes in Section 6 with a set of recommendations.

Originally reported in the Ugandan press (Ladu 2014), government interviewees confirmed that the review was underway.

Interview with Finance Ministry officials, Kampala, September 2014.

Figures calculated by the authors based on IBFD (2016). 


\section{Tax treaties: a brief survey of the literature}

Bilateral tax treaties are the fundamental building blocks of the international tax regime emerging from the work of the League of Nations in the first half of the $20^{\text {th }}$ century, in response to concerns raised by the International Chambers of Commerce that conflicting claims by different countries to tax the same income earned by multinationals was leading to double taxation, which increased the cost of investing overseas (Picciotto 1992). The core settlement embodied in tax treaties has changed very little since the League of Nations' model treaty was first published in 1928 (Avi-Yonah 2007): capital-importing countries accept curbs on their ability to tax investors from the treaty partner, and in return the treaty partner bears the cost of relieving any double taxation that its outward investors incur.

Tax treaties give capital-importing countries the primary right to tax active or earned income, the profit from activities in which the recipient of the income plays an active role, such as if it has a branch in the other country. The capital-importing country may tax a foreign investor's active business income originating within its borders, but only when the investor's physical presence passes a certain threshold, known as a permanent establishment. In the absence of a treaty, the capital-importing country would be able to levy a tax on any income earned within its borders, regardless of the type or extent of a company's or person's presence, so long as it is able to enforce the tax.

On the other hand, they give capital-exporting countries the primary right to tax passive or unearned income from activities in which the foreign investor is not actively involved, such as royalties for the use of intellectual property that it owns. Tax treaties do allow the capitalimporting country to levy a withholding tax (WHT) on some of these passive income flows, but they set a maximum tax rate that is usually lower than the rate in domestic law, and which applies regardless of changes to the statutory rates for as long as the treaty is in force.

While the individual thresholds and other modalities must be negotiated on a bilateral basis, the structure of the international models means that whenever a treaty is concluded between two countries with asymmetrical flows of people and investment, as between a developing country and a developed country, the treaty will shift the balance of taxing rights away from the capital importer and towards the capital exporter. It is argued that the former will benefit from tax treaties where the welfare gains from increased inward investment outweigh the fiscal costs (Becker and Fuest 2012; Rixen and Schwarz 2009).

This basic argument comes under attack from two directions. A long tradition of critical legal scholarship argues that it is a myth, because capital-exporting countries already relieve the bulk of any double taxation unilaterally: their tax systems give outward investors a credit for taxes paid overseas, or exempt foreign-source income from taxation altogether. In that case, it is argued, tax treaties merely shift the burden of double taxation relief away from the capital exporter, who bears it in the absence of a tax treaty, and onto the capital importer (Avi-Yonah 2009; Dagan 2000; Thuronyi 2010). This attack is partly countered by pointing to the broader list of functions of tax treaties, including mopping up any outstanding double taxation that is not resolved unilaterally, guaranteeing more stable and predictable tax treatment for investors, and reducing what might be regarded as high WHT rates (Jones 1999; Pickering 2013; Self 2014). It is also argued that even if the costs outweigh the benefits in a bilateral setting, a country with more treaties may attract more investment due to tax competition with others (Baistrocchi 2008; Barthel and Neumayer 2012).

The second attack is perhaps more difficult to surmount. The evidence that tax treaties have a positive effect on investment flows into developing countries is far from clear. Until 2009, studies found a mixed effect - positive, neutral or even negative - but no positive effects for developing countries (Sauvant and Sachs 2009). Since then, some research has found 
evidence of a positive association by using more comprehensive bilateral investment data (Barthel et al. 2009; Lejour 2014), or microdata drawn from databases of individual companies' financial structures (Blonigen et al. 2014; Davies et al. 2009; Egger and Merlo 2011). Even these studies fall far short of clear evidence, due to several limitations. First, these datasets tend to have poor coverage of developing countries, especially in the case of microdata: of the three microdata studies, only Davies et al. use a dataset with sufficient coverage of sub-Saharan Africa to be able to draw any conclusions. Secondly, investments commonly make use of treaty shopping, as shown in the case of the Netherlands by Weyzig (2012). Thirdly, treaties may follow, rather than provoke, an influx of investment, and both decision-making processes can have significant lag times, creating endogeneity. Finally, there may be competition effects in the developing country market, because a tax treaty may increase investment from a treaty country by allowing them to make greater profits than other firms, rather than creating additional investment.

These legal and economic questions may be resolved through qualitative evidence, especially from in-depth case studies that allow for the identification of particular issues in the interaction of treaty partners' tax systems, and for an examination of the volume and nature of investment flows between treaty partners. Furthermore, they allow for the inclusion of political variables. There is already evidence from Ghana (Christians 2005), Colombia (Quinones Cruz 2012) and Uganda (Aukonobera 2012; Kangave 2009) that tax treaty networks may not always be the product of rational negotiation founded on a strategy of investment promotion combined with revenue maximisation. This builds on similar claims made in the literature on bilateral investment treaties (Jandhyala et al. 2011; Poulsen 2014; Tobin and Rose-Ackerman 2011; Yackee 2005).

The remainder of this paper presents just such a study. It is based primarily on interviews with government officials and private sector tax advisers conducted in Kampala in September 2014, using a snowball sampling method. These are supplemented by documentary evidence from Uganda's parliamentary record (Hansard), court judgements and other official documents, as well as analysis of treaty texts and domestic laws, and data on investment flows.

\section{Unconvincing explanations for the development of Uganda's tax treaty network}

This section critically examines the explanations given by various stakeholders for Uganda's tax treaties. One surprising outcome from our interviews is that hardly anyone familiar with Uganda's tax treaties, whether in the private sector or in government, or even at the Uganda Investment Authority (UIA), believes that tax treaties have much effect on the amount of inward investment into the country. Despite this, most of the reasons offered up for tax treaties in Uganda still relate to investment promotion. Here we critically examine each in turn.

\subsection{Investment promotion and 'tax sparing'}

Aside from its 1968 treaty with Zambia, independent Uganda did not successfully conclude a tax treaty until 1992, when it signed with the UK. But it did negotiate before that time. For example, drafts were exchanged with the UK in the 1970s. It is unclear from British government records why these negotiations failed, but Uganda's demand for a 40 per cent withholding tax on royalties, consistent with its domestic legislation, was clearly an obstacle. ${ }^{5}$

Correspondence from archived Inland Revenue file IR 40/17815. 
Talks with the UK were also revived in the early 1980s, but it appears that it was not until the start of the 1990s that Uganda decided it was willing to make the sacrifices demanded by the UK in order to obtain a tax treaty. ${ }^{6}$ This change of heart coincided with reforms to create a more attractive environment for investors, many of which were embodied in the 1991 Investment Code Act.

The role played by tax treaties in this new investment framework was set out by Uganda's Minister for Finance, Planning and Economic Development in 1993, announcing that the government would 'embark on negotiating double taxation agreements with identified major trading partners'. ${ }^{7}$ As the Minister explained, the purpose of the treaties was to 'ensure that the effectiveness of current incentives is not eroded by the absence of complementary tax credits' because 'in the absence of any complementary tax holidays with the home countries of foreign investors, the revenue foregone by reducing a company's tax liability in Uganda represents a revenue gain by the Ministry of Finance in the home country'. ${ }^{8}$ The reasoning was that by including tax sparing provisions in a treaty, the treaty partner would agree to allow a credit for taxes due but foregone by Uganda due to investment incentives, thus ensuring that the benefit from the tax incentives accrued to the multinational investors at whom they were targeted. To underline the link with investment incentives, in the early 1990s the UIA also participated in treaty negotiations. ${ }^{9}$

It took some time for the negotiating programme announced in 1993 to come to fruition, but three of Uganda's subsequent tax treaties did include such tax sparing provisions: South Africa (1997), Italy (2000) and Mauritius (2003). ${ }^{10}$ After 1993, however, two other factors combined to undermine this rationale for treaty negotiation. First, in 1998, the OECD published Tax Sparing: a Reconsideration, which highlighted the potential negative impacts of tax sparing arrangements in tax treaties, in particular that they could potentially be abused, and that they created an incentive to repatriate profits quickly rather than reinvest them in a country (OECD 1998). This OECD report on its own did not halt the spread of tax sparing provisions, although it did suggest some best practice in the area.

A second development was the spread of territorial tax systems throughout the OECD countries, under which a capital-exporting country exempts the foreign-source income of its outward investors from further taxation (PWC 2013). Under a territorial system, overseas investors automatically keep the gains from any tax concessions in the host country, whether or not a tax treaty is in place. Italy was already operating an exemption system at the time the treaty with Uganda was signed, and both South Africa and the UK now also exempt foreign-source dividends from direct investments from further taxation.

\subsection{Relieving double taxation}

Although their negotiated content indicates that tax sparing ceased to be Uganda's main justification for tax treaties, it continued to sign them - with Norway (1999), Denmark (2000), the Netherlands (2004), India (2004) and Belgium (2007). A treaty with China was concluded in 2012, but has not yet been ratified. According to statements made in budget speeches, Uganda has also negotiated with Egypt, the Seychelles, Sudan, Turkey and the United Arab Emirates. ${ }^{11}$

Interview with Finance Ministry official, Kampala, September 2014.

Mr. J. Mayanja Nkangi, quoted in Hansard, 25.6.93.

Ibid.

Interview with UIA official, Kampala, September 2014.

Mauritius levies corporation tax at $15 \%$ on overseas income, but most investors in Uganda from Mauritius use the Global Business Company (GBC) form that attracts a rate of only $3 \%$, making the benefits of sparing largely irrelevant.

Because the GBC rate is effectively a tax incentive reducing the rate by 12 percentage points, it is possible that Ugandans can use Mauritius for 'round tripping', to avail themselves of the tax sparing clause.

11 Budget speeches, Hansard 10 June 2004, 12 June 2008, 19 September 2013. 
The government's rationale for these treaties, set out by successive finance ministers when laying the treaties before parliament, has changed since 1992. According to Mr G. Ssendula in 2001, it was now 'to protect taxpayers against double taxation, and to ensure that the tax system does not discourage direct foreign investment'; Dr Ezra Suruma concurred in 2006, that 'the purpose of this agreement is to reduce tax impediments to cross-border trade and investment and assisting tax administration in information sharing'. ${ }^{12}$

The difficulty with this view is that there are very few instances in which potential double taxation on investors in Uganda in the absence of these treaties can really be identified. All Uganda's treaty partners take unilateral steps to relieve double taxation: the European countries all treat foreign-source dividends from direct investments as tax-exempt, as does South Africa; India, China and Mauritius provide a tax credit. Australian investors, by far the biggest non-treaty bloc according to Uganda's investment statistics, seem to have had no concerns about tax when investing in Uganda, which may be because that country also exempts foreign source dividends. ${ }^{13}$

Another argument often touted is that investor confidence is boosted by inclusion of the mutual agreement procedure (MAP) in Uganda's tax treaties, which provides a procedure for resolution of claims of double taxation. However, it is also a good indicator of post-treaty complaints of double taxation. Revenue officials indicate that, after twenty-two years, Uganda has yet to enter into a MAP. ${ }^{14}$ A potential new case with the UK cited by Uganda Revenue Authority (URA) officials does not seem to concern double taxation, but is about which of two options provided in that treaty's management fees article should be used.

This is not to say that potential double taxation issues don't exist. Kenya, with which Uganda does not have a treaty, ${ }^{15}$ does not give a credit for taxes paid overseas unless a tax treaty is in place. Instead, it allows Kenyan companies to deduct foreign taxes paid as an expense, which arguably entails some double taxation. Differences in definition or interpretation can also create double taxation in some instances: for example, where a fee paid to a company in one country for providing a service to a company in the other is regarded by both countries as originating within their borders. From Uganda's perspective, it is unlikely (but not impossible) that this alone is sufficient reason for a treaty.

In any event, the trite rationale that 'treaties relieve double taxation, which attracts investment', which still dominates discussion of tax treaties in Uganda, simply does not hold in the case of Uganda's existing treaties. While in the absence of tax treaties there would no doubt be some investors who would be inconvenienced by some double taxation, it cannot be assumed that, in the absence of a treaty, a definite flow of investments would be choked off due to significant double taxation.

\subsection{Treaties as tax incentives}

There may be no major double taxation problem, but tax treaties may still attract investment into Uganda because of their effect on single taxation. This is because many of Uganda's major investment partners exempt foreign income from taxation altogether. Hence, the lower withholding taxes and other restrictions on source taxation in Uganda's tax treaties effectively act as tax incentives, lowering the overall cost for firms from these countries of investment in Uganda.

Budget speeches, Hansard 14 June 2001 and 15 June 2006.

Although Uganda is not a substantial outward investor itself, it also relieves double taxation for Ugandan residents through a credit for taxes paid abroad.

Interview with URA officials, Kampala, September 2014

Kenya and Uganda are both signatories to the EAC's multilateral tax treaty, which has yet to be ratified by all member states. 
Although this is no doubt positive for investors, there was a startling consensus across the stakeholders we interviewed that tax treaties were not a primary consideration for investors in deciding whether or not to invest in Uganda. A MoFPED official, despite the statements made by past finance ministers, stated boldly that 'nobody comes to invest because you have a tax treaty. When you see the rationale to attract investment, it sounds laudable. But when you look at the evidence, it's not the case'. ${ }^{16}$ According to an accountant in a tax advisory firm, 'it is a secondary factor you take into account in terms of structuring'. ${ }^{17} \mathrm{~A}$ tax lawyer agreed:

It would seem to me that tax is a secondary consideration. From our experience we have seen investors are looking to the economic drivers: business-based, rather than tax-based. A business will say 'now we have decided where we are going to work, let's get a tax expert to structure it'. ${ }^{18}$

Unlike other developing countries, promotional literature from Uganda's Investment Authority does not mention its network of tax treaties. ${ }^{19}$ An official there told us that investors are not interested in tax treaties: 'to most of them it is not an important thing'. ${ }^{20}$ Indeed, tax treaties are not mentioned anywhere in a comprehensive survey of investors conducted by the UIA and Uganda's National Bureau of Statistics. ${ }^{21}$ Among economic and financial factors affecting business, more than half of those surveyed said corporate tax had a low or no effect; only 15 per cent said it had a significant negative effect, which was second to bottom among the thirteen factors listed. ${ }^{22}$

Uganda's investment statistics, presented in Table 1, shed some further light on this. Inward foreign direct investment (FDI) stocks reported by Uganda are dominated by $\$ 3.7$ billion from the Netherlands, but the Netherlands (whose data on outward investments exclude special purpose vehicles used in treaty shopping) reports only $\$ 179$ million of FDI in Uganda. This suggests that 95 per cent of investment coming into Uganda from the Netherlands originates elsewhere. Investment from Mauritius into Uganda, at \$381 million, does not appear to be as large as one might expect, given the talk of Mauritius in Kampala tax circles. But the fact that it exceeds investment from both South Africa and Kenya is notable. 'Most of the companies investing in Africa have been setting up through a hub in Mauritius', a tax adviser stated. ${ }^{23}$ URA officials concurred, with one asserting that 'there is a lot of treaty shopping. A lot of companies trading in Uganda have their HQs in Mauritius'. ${ }^{24}$

The second biggest source of investments, also much bigger than any others, is Australia, which has no treaty with Uganda. New investment in Uganda's oil industry has come from the French company Total and the Chinese National Offshore Oil Corporation, neither based in countries that have tax treaties with Uganda.

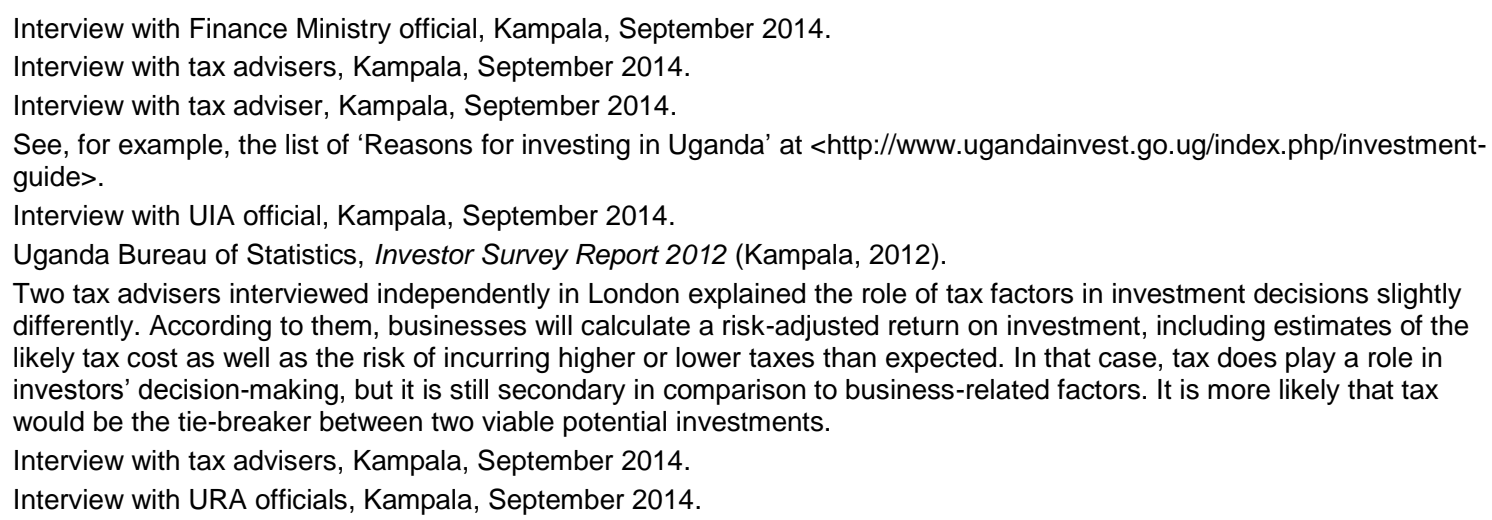


Table 1 Investment stock in Uganda, 2012

\begin{tabular}{|l|l|r|r|}
\hline Home country & Treaty? & $\begin{array}{l}\text { FDI equity } \\
\text { stock in } \\
\text { Uganda in } \\
\text { 2012 (US\$) }\end{array}$ & $\begin{array}{l}\text { FDI debt } \\
\text { stock in } \\
\text { Uganda in } \\
\text { 2012 (US\$) }\end{array}$ \\
\hline Netherlands & Yes & 3,729 & 198 \\
\hline Australia & No & 1,736 & 412 \\
\hline United Kingdom & Yes & 688 & 136 \\
\hline Mauritius & Yes & 381 & 86 \\
\hline Kenya & No & 312 & 105 \\
\hline Switzerland & No & 99 & 14 \\
\hline India & Yes & 99 & 9 \\
\hline United States & No & 94 & 9 \\
\hline Bermuda & No & 88 & 1 \\
\hline South Africa & Yes & 64 & 11 \\
\hline Norway & Yes & 28 & 28 \\
\hline Denmark & Yes & 3 & \\
\hline Belgium & Yes & -26 & \\
\hline
\end{tabular}

Source: IMF (2014).

Note: data from some significant investors, notably China, is not available.

In conclusion, we might observe that the only treaty for which there is evidence of a major impact on investment into Uganda is the Dutch one, but this effect has been to encourage treaty shopping rather than to stimulate significant amounts of Dutch investment. When private sector tax advisers were asked what would happen if the Dutch treaty were cancelled, they stated that investors would simply restructure, and were unlikely to withdraw their investments.

\subsection{Fiscal cooperation}

Tax treaties nowadays also may include provisions for cooperation between tax authorities in the form of information exchange and assistance in the collection of taxes. Broader arrangements for mutual assistance are also available through multilateral conventions. As Table 2 shows, however, Uganda's bilateral treaty network is somewhat patchy in its provision of some of these benefits.

Table 2 Fiscal cooperation provisions in Uganda's tax treaties

\begin{tabular}{|l|c|c|c|c|c|c|c|c|c|c|c|}
\hline & Zambia & UK & $\begin{array}{l}\text { South } \\
\text { Africa }\end{array}$ & Norway & Denmark & Italy & Mauritius & India & $\begin{array}{l}\text { Nether } \\
\text { lands }\end{array}$ & Belgium & China \\
\hline $\begin{array}{l}\text { Date of } \\
\text { signature }\end{array}$ & 1968 & 1992 & 1997 & 1999 & 2000 & 2000 & 2003 & 2004 & 2004 & 2007 & $2012^{25}$ \\
\hline $\begin{array}{l}\text { Information } \\
\text { exchange }\end{array}$ & Yes & Yes & Yes & Yes & Yes & Yes & Yes & Yes & Yes & Yes & Yes \\
\hline $\begin{array}{l}\text { Collection } \\
\text { of taxes }\end{array}$ & No & No & Yes & Yes & Yes & No & No & Yes & Yes & Yes & No \\
\hline
\end{tabular}

Information exchange provisions allow a revenue authority from one country to obtain information about its taxpayers that the other country may hold - for example, if the other country is the home country of a multinational whose subsidiary the first country is auditing, or if an individual being investigated has savings in the other country. Revenue officials indicated that Uganda has historically made at the most 'maybe one request per year' using the powers in its tax treaties, ${ }^{26}$ although this situation may be improving: between the URA's Tax Investigations Department becoming the competent authority with powers to administer tax treaties in March 2014 and an interview conducted in June 2015, the URA had made

\footnotetext{
25 While IBFD (2014) states that this treaty was signed in 2012, MofPED officials claim it has not yet been signed.

$26 \quad$ Interview with URA officials, Kampala, September 2014.
} 
eight new requests for information (Kangave et al. 2016). Uganda is part of a pilot automatic tax information exchange project with the UK, but URA officials indicated that, even under this, they do not expect to gain much in the short- to medium-term. So while this might be an important tool to combat tax evasion in principle, in practice it is a tool from which Uganda is only just starting to benefit.

There may be more benefit to Uganda from the legal basis created by modern treaties for the tax authority of one country to collect taxes on behalf of the other. A URA official explained that this could be important for the URA in cases such as the Zain capital gains dispute (discussed below), or in cases of short duration permanent establishments, where the taxpayer concerned no longer has any assets in Uganda by the time that an assessment is raised. ${ }^{27}$ It is unfortunate that many of Uganda's treaties, including the potential one with China, do not include this provision.

Having noted these advantages, it is important to realise that Uganda does not need bilateral tax treaties to obtain them. They can be obtained through two multilateral conventions. One, initiated by the African Tax Administration Forum (ATAF), covers African countries including Mauritius, but is not yet in force. ${ }^{28}$ The other, which is in force and which Uganda signed in November 2015, was initiated by the Council of Europe and the OECD, and covers all Uganda's treaty partners. ${ }^{29}$ Multilateral conventions have further advantages. First, they provide for broad mutual assistance, and on a multilateral basis, which, for example, would permit joint assessment of a multinational by a consortium of tax authorities. This issue was thrown up as a result of a multi-country investigation conducted by the NGO ActionAid into the multinational brewery SABMiller, which owns Uganda's main brewery, Nile (Hearson and Brooks 2010). The report provoked a desire in African tax authorities to conduct their own investigations, to combine forces and examine apparently similar tax avoidance practices across the continent. Unfortunately, they lacked the legal authority to do so, needing a single multilateral treaty covering all the relevant countries. ${ }^{30}$

\section{Problems with the content of Uganda's existing treaties}

It would be unfair to say that Uganda has negotiated badly in the past. In fact, among subSaharan countries its treaties are among the best when it comes to the protection of some taxation rights such as withholding taxes on management fees. However, this makes Uganda a good performer within a region that has systematically negotiated away large chunks of its taxing rights, especially in comparison with other regions (Dauer and Krever 2012). In this section we demonstrate that a lifting of these low expectations leads very quickly to a much more negative assessment of Uganda's tax treaty network.

It should be made clear that treaties are about taxing rights, not tax rates or even revenue. This means that the question to be asked when accepting a limitation in a treaty is not 'How much tax should investors into Uganda pay?', but 'How much should Uganda constrain its right to levy tax now and in the future?' The first is a question to be asked by reference to the current economic situation and economic policy. The second entails anticipating future events and priorities. In signing a treaty, a country accepts limitations on what future

Interview with URA officials, Kampala, September 2014.

ATAF Multilateral Convention on Mutual Assistance.

The Multilateral Convention on Mutual Assistance, formerly the OECD/Council of Europe Multilateral Convention on Mutual Assistance. Mauritius has recently signed but not yet ratified it.

See 'What happened next' in 2012 update to Hearson and Brooks (2010). 
governments, or even the same government in different economic circumstances, can do. The maximum withholding tax rates and other restrictions in treaties should be considered in this context of restricting future actions, rather than in terms of advisable tax policy in the current economic situation.

\subsection{Uganda's treaty network is much less favourable than the UN model treaty}

MoFPED officials suggested to us that, in its negotiations, Uganda has generally followed the UN model tax convention, but sought to include an article permitting withholding taxes on management service fees. ${ }^{31}$ Most negotiating partners' own opening positions are likely to have begun from the OECD model. Table 3 shows a selection of the results from these negotiations. The UN model is described in its title as a model for treaties 'between developed and developing countries', and is the most widely-recognised articulation of a good balance of taxing rights between developed and developing countries. Using it as an opening position has evidently not served Uganda well as a tool to achieve this eventual balance.

Table 3 Selected provisions of Uganda's tax treaties



Notes: Items in red give Uganda fewer taxing rights than the UN model.

I The Uganda-Zambia treaty gives exclusive source taxing rights over interest and royalties.

ii Uganda's tax code does not distinguish between FDI and portfolio dividends, but some of its treaties do.

iii This provision is not currently part of the UN model, but is often included in sub-Saharan treaties.

31 Interview with Finance Ministry officials, Kampala, September 2014.

32 While IBFD (2014) states that this treaty was signed in 2012, MofPED officials claim it has not yet been signed. 


\subsubsection{Withholding tax rates}

As noted earlier, tax treaties set maximum rates at which withholding taxes can be levied on cross-border payments, specifically dividends, interest, royalties and management or technical service fees. In Uganda's tax code, these payments are all taxed at 15 per cent, but the treaty rates shown in Table 3 are mostly lower than this. Uganda has indeed been broadly successful at maintaining the right to levy a withholding tax on management fees paid to foreign companies, and the other withholding tax rates have historically compared well to those of many other African countries. However, these rates have trended down since its first treaty with the UK, in particular in the more recent treaties with the Netherlands, Belgium and China. It is worth noting the recent experience of Zambia, whose generous concessions to China appear to have created a precedent, pushing down withholding taxes quite significantly in a subsequent renegotiation with the UK (Hearson 2014).

Uganda's treaties generally set maximum rates that are below the rates in its domestic law. The treaty rates in Table 3 should be compared to the statutory 15 per cent rate levied on all these types of payments in Ugandan law. Table 4 gives an estimate of the revenue foregone as a result of the reduced dividend and interest withholding tax rates stipulated by tax treaties. It indicates that for these taxes the Dutch treaty may dwarf all others, with a cost of between 22 billion and 63 billion shillings per year (around US\$8 million to US\$24 million). Only the Mauritius treaty comes close, at 2.6 billion shillings (about US $\$ 1$ million). These figures exclude the cost of lower withholding taxes on royalties and management fees, where data is not available, but which are likely to create significant further costs. 'We realised that a lot of money was flying out through management fees', a Finance Ministry official told us. ${ }^{33}$

\section{Table 4 Estimated revenue foregone due to reduced WHTs in treaties (Ugandan} shillings, billion)

\begin{tabular}{|c|c|c|c|c|c|c|}
\hline & \multicolumn{2}{|c|}{ FDI stock in Uganda } & \multicolumn{2}{|c|}{ Estimated return on FDI } & \multicolumn{2}{|l|}{ WHT foregone } \\
\hline & Equity & Debt & Dividends & Interest & Dividends & Interest \\
\hline Netherlands & 9,899 & 525 & 414 & 22 & 21 to $62^{*}$ & 1.1 \\
\hline Mauritius & 1,012 & 229 & 42 & 9.6 & 2.1 & 0.5 \\
\hline India & 263 & 23 & 11 & 1.0 & 0.5 & 0.0 \\
\hline South Africa & 169 & 119 & 7.1 & 5.0 & 0.4 & 0.2 \\
\hline Norway & 77 & 1.9 & 3.2 & 0.1 & 0.2 & 0.0 \\
\hline Denmark & 9 & 30 & 0.4 & 1.3 & 0.0 & 0.1 \\
\hline
\end{tabular}

Source: IMF (2014). Assumes a uniform 4.1\% return on FDI from Uganda based on <data.worldbank.org>.

*Treaty rate is most likely $0 \%$, but for some companies it may be $5 \%$ (for holdings below $50 \%$ ) or $15 \%$ (for companies not composed of shares).

\subsubsection{The definition of permanent establishment}

Withholding tax rates are a first line of defence against tax avoidance, since they discourage abusive transfer pricing payments. Because they are levied on the gross value of payments, however, they can lead to onerous levels of taxation if margins are slim, unlike taxation of net profits; in the case of branches, which do not remit profits as dividends, profit taxation is necessary. Effective taxation of net profits in such circumstances depends on building a broad definition of permanent establishment, which sets the minimum threshold of activity before a company can have tax levied on its profits, into treaties. Many of Uganda's treaties lack this. 'Withholding tax rates are nothing', a Finance Ministry official told us. 'You can have high rates and then you've given out a lot in PEs'. ${ }^{34}$

As an example of this debate, one particular concern for the MoFPED is the taxation of oil exploration activities. The treaties with the Netherlands and Denmark include a special oil 
exploration permanent establishment (PE) to tax the profits from such activities, the threshold for which is a minimum presence in the country of thirty days. Several tax advisers, however, felt that withholding taxes levied on the fees paid to specialist service providers in the oil industry would have been a more effective option, since it is easier for their oil industry clients to avoid being taxed as a PE. One said that Uganda should be asking, 'What is it we can have a quick win on, which will not have so much complexity in terms of enforcement?' He continued, 'Oil service providers, for example, will always structure to avoid PE risk' ${ }^{35}$

A first weakness in the PE definitions within Uganda's tax treaties is the absence from most of them of the UN service PE provision, which expands the PE threshold to encompass service providers who are physically present in the country but do not operate from a 'fixed base', otherwise the starting point of the PE definition. The UN service PE provision is contained in half of recent treaties signed by developing countries (Wijnen et al. 2012). ${ }^{36}$ Furthermore, none of Uganda's treaties include the less commonly used UN 'limited force of attraction' provision, which would allow inclusion of all a multinational's profits from similar activities in Uganda within the profits of its permanent establishment. Both this and the service PE provision would expand the tax base of multinational enterprises operating in Uganda.

Another weakness is in the length of time a construction site must be in place before it meets the PE definition. In common with around half the recent treaties signed by developing countries, Uganda has consistently obtained a six-month construction PE, which is more advantageous than the twelve months specified in the OECD model and the most common length in recent treaties signed by developing countries. But the six- and four-month thresholds in Uganda's tax treaties may not be short enough in an era where, as one Finance Ministry official pointed out, 'the Chinese can do things in three months'. ${ }^{37}$

\subsubsection{Capital gains}

Finally, the treaties' capital gains provisions are problematic, because they restrict Uganda's right to tax gains realised by foreign investors on sales of Uganda-based assets. First, only the India and China treaties include an anti-avoidance provision that would allow Uganda to tax sales of companies overseas that are vehicles for the ownership of immovable property in Uganda. This provision has been included even in the OECD model, and is found in almost two-thirds of recent treaties signed by developing countries. Its absence is at the heart of the Zain case (see below). Second, only Uganda's treaties with India and Norway permit it to tax the sale of shares in a Ugandan company by foreign residents. This provision is also included in the UN model. Combined, these two omissions are a recipe for serial losses, discussed further below.

\subsection{There is evidence of significant revenue loss due to preventable treaty shopping}

Treaty shopping refers to the practice of establishing a conduit company in a country with a favourable network of tax treaties, and usually a low effective tax rate, to take advantage of the benefits of those treaties rather than the less generous terms (if there is a treaty at all) negotiated between the investor's home country and the destination of their investment (Cooper 2014). As already noted, the vast majority of investment from the Netherlands into Uganda appears not to originate there. Given that it enables a zero rate on dividends, it is easy to see why. ${ }^{38}$ According to a URA official, 'The ones claiming [reduced taxation] under

Interview with tax adviser, Kampala, September 2014.

Further references to 'recent treaties signed by developing countries' are also taken from this study.

Interview with Finance Ministry official, Kampala, September 2014

See also Kangave (2009). 
the DTAs are many, about one per day. The worst culprits are Mauritius, Netherlands. There is a lot of treaty shopping. A lot of companies trading in Uganda have their HQs in Mauritius'. ${ }^{39}$ Consider Uganda's booming mobile communications sector. Major investments come from countries that have a treaty with Uganda, but they have been structured via third countries with more favourable treaties. Bahti Airtel is headquartered in India, but its investment is structured via the Netherlands; MTN is headquartered in South Africa, with its investment structured via Mauritius (Kalinaki 2014; MTN Group PIc 2014).

An important advantage to investors of Uganda's treaties with the Netherlands and Mauritius is that they provide an easy treaty shopping route to avoid Ugandan capital gains tax. The treaties prevent Uganda from taxing the sale of shares in Ugandan companies by a Dutch or Mauritian resident, and may allow foreign investors to avoid capital gains tax on the sale of immovable property in Uganda simply by structuring the purchase through a vehicle in the Netherlands or Mauritius. The issue of 'indirect transfers' of capital assets has been highlighted by the United Nations (Cui 2014), IMF (2014a: 28) and OECD (2014b), the latter stating in its recent report to the G-20 development working group that:

Developing countries report that the profit made by the owner of an asset when selling it (for example, the sale of a mineral licence) is often not taxed in the country in which the asset is situated. Artificial structures are being used in some cases to make an 'indirect transfer'; for example through the sale of the shares in the company that owns the asset rather than the sale of the asset itself.

(OECD 2014b: 16)

It is therefore concerning that, as Table 3 shows, so few of Uganda's treaties include provisions concerning the taxation of gains from the alienation of shares, whether general shares or those in property-rich companies. The Dutch and Mauritian treaties present a particular problem here: with around 11 trillion Ugandan shillings (US\$4 billion) of direct investment stocks in Uganda coming through these two countries (see Table 4), a potential billion dollars of capital gains tax is at risk that might otherwise be payable in Uganda. ${ }^{40}$

As one example, the URA is currently in dispute with Zain Telecom over $\$ 85$ million of capital gains tax in exactly such an indirect transfer case. The sale of Celtel Uganda Ltd from Zain Telecom to Bahti Airtel took place via a network of holding companies in the Netherlands. The URA maintains that Celtel Uganda was a company consisting predominantly of immovable capital, and that as such it should be able to tax the transfer even though it took place in the Netherlands. ${ }^{41}$ Unfortunately, because the Uganda-Netherlands treaty does not contain a clause concerning property-rich companies, it allocates the right to tax this transaction to the Netherlands. When the case moves from technicalities to substance, the URA will no doubt point to section 88(5) of the Income Tax Act, an anti-treaty shopping provision which provides that:

Where an international agreement provides that income derived from sources in Uganda is exempt from Ugandan tax or is subject to a reduction in the rate of Ugandan tax, the benefit of that exemption or reduction is not available to any person who, for the purposes of the agreement, is a resident of the other contracting state where 50 per cent or more of the underlying ownership of that person is held by an individual or individuals who are not residents of that other Contracting State for the purposes of the agreement.

Interview with URA official, Kampala, September 2014.

The Uganda-Netherlands treaty does contain a provision that holds a Ugandan resident who becomes Dutch liable for Ugandan tax on capital gains for ten further years.

41 Court of Appeal of Uganda, Commissioner General, URA versus Zain International BV, 2012. 
There is a lot of uncertainty among tax professionals in both public and private sectors about whether an Income Tax Act such as this one can override the provisions of a tax treaty. ${ }^{42}$

Section 88(2) of the Act gives treaties precedence over domestic law except for clause 88(5) and other anti-avoidance rules, but Uganda is also a signatory to the Vienna Convention on the Law of Treaties which may prevent 'treaty overrides' in domestic law. This case may provide some useful jurisprudence, but, absent a favourable court judgement, Uganda can only safeguard its taxing rights effectively by including anti-avoidance provisions within its treaties themselves. Furthermore, the 'underlying ownership' concept is relatively untested, and according to tax advisers there is an absence of procedural guidance from the URA explaining how taxpayers can demonstrate compliance. A concern mentioned by Ugandan tax advisers is the application of the underlying ownership concept to public limited companies, whose shareholders are numerous, geographically diverse, and constantly changing. ${ }^{43}$

The OECD (2014a) is currently developing a general anti-abuse rule for inclusion in model treaties, based on a different form of anti-avoidance rule - a principle purpose test. Uganda would be well advised to follow this aspect of the OECD's Base Erosion and Profit Shifting (BEPS) project, and to consider incorporating a rule along these lines into its treaties (none currently contains an anti-abuse rule), as well as amending its domestic law to match. It may be able to do so through participating in the proposed multilateral instrument to introduce amendments into existing tax treaties.

In any event, the Zain case could have been prevented without the need for a general abuse clause if Uganda had simply ensured that the specific anti-abuse rule relating to capital gains tax provided for by both the UN and OECD model treaties at article 13(4) was incorporated into its treaties, as it is in half of recent treaties signed by developing countries (Wijnen and de Goede 2013). The UN model contains a number of such specific anti-abuse rules, but their incorporation into Uganda's treaties is patchy (Table 5). Some, such as the 'beneficial owner' and 'special relationship' wording in the UN and OECD model clauses on WHT are present in all Uganda's treaties. However, several others are barely included, if at all. This includes the incorporation of a dependent agent maintaining stock in the definition of permanent establishment, and the limited force of attraction and capital gains provisions discussed earlier.

Table 5 Examples of specific anti-abuse rules from the UN model in Uganda's tax treaties

\begin{tabular}{|c|c|c|c|c|c|c|c|c|c|c|c|c|}
\hline Article & Description & $\begin{array}{l}\frac{\pi}{0} \\
\frac{0}{E} \\
\text { N }\end{array}$ & 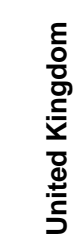 & 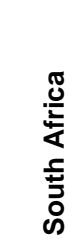 & $\begin{array}{l}\text { बे } \\
\text { 잉 } \\
\text { Z }\end{array}$ & बत & 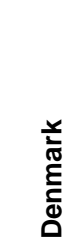 & 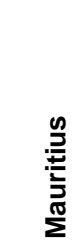 & 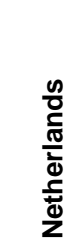 & $\stackrel{\frac{\pi}{0}}{\underline{\underline{g}}}$ & $\frac{E}{\frac{5}{5}}$ & : \\
\hline & Year signed & 1968 & 1992 & 1997 & 1999 & 2000 & 2000 & 2003 & 2004 & 2004 & 2007 & $2012^{44}$ \\
\hline $5(5)(b)$ & $\begin{array}{l}\text { Dependent agent } \\
\text { maintaining stock }\end{array}$ & Yes & No & No & No & No & No & Yes & No & Yes & No & No \\
\hline $7(1)(b \& c)$ & $\begin{array}{l}\text { Limited force of } \\
\text { attraction }\end{array}$ & No & No & No & No & No & No & No & No & No & No & No \\
\hline $13(4)$ & $\begin{array}{l}\text { Capital gains - } \\
\text { property rich }\end{array}$ & NA & No & No & No & No & No & No & No & Yes & No & Yes \\
\hline
\end{tabular}

42 Interviews with tax advisers and with URA officials, Kampala, September 2014.

$43 \quad$ Interviews with tax advisers, Kampala, September 2014

$44 \quad$ While IBFD (2014) states that this treaty was signed in 2012, MofPED officials claim it has not yet been signed. 


\section{Problems with model treaties}

As noted earlier, Uganda may have opened its treaty negotiations with a preference for the UN model, but it rarely obtained UN model provisions for many articles. The UN model is a compromise position between developed and developing countries, developed by a group of tax officials nominated by both developed and developing countries: in other words, it is the outcome developing countries should aim for, not the opening position from which they should begin negotiations. There is a need for a model that fulfils this latter role.

Precedent is powerful in treaty negotiations, and any changed approach to negotiations must bear this in mind, rather than plucking articles from nowhere. The best way to build precedent at this point is twofold: first, shape internationally-accepted models to reflect Uganda's policy goals; second, negotiate strategically among like-minded countries to create precedent. Here we consider some examples.

\subsection{Uganda and the UN model}

Model tax treaties don't stay static, they evolve. If Uganda is to adopt the UN model as its own negotiating model, it should be involved in shaping that model to reflect its own concerns. For example, the committee that updates the UN model treaty is currently considering the introduction into the treaty of a provision permitting withholding taxes on management service fees, which has always been a priority for Uganda in negotiations. The provision has been the subject of much disagreement among committee members. ${ }^{45}$ If it is adopted, this may help bolster Uganda's position in negotiations, but a weaker version than that currently used by Uganda could have the opposite effect.

There is no Ugandan member on the UN tax committee, and indeed there has not been since the committee was given its current status in 2005. It would still be possible to influence the UN's work, for example by attending meetings as an observer: many observers make verbal contributions to committee meetings, where they have the benefit of speaking on behalf of their country, rather than in a personal capacity as committee members do. However, Uganda has not attended a UN committee session since 2004, nor does it appear to have submitted written comments to recent UN consultation exercises. ${ }^{46}$ Another possibility would be to coordinate with the actual UN committee members, for example those from Africa - of which there are five, from Ghana, Zambia, Senegal, South Africa and Morocco. Finance Ministry officials indicate that they do not take this opportunity either. ${ }^{47}$

An important reason to engage with the work of the UN committee is the role its commentary may play in any treaty dispute arising from a clause based on the UN model. Unlike the OECD model (discussed below), countries cannot enter observations or reservations on the text or commentary; instead the commentary notes any difference of opinion between members concerning the treaty's interpretation. If Uganda wishes the treaty to be interpreted in a particular way, it would need to ensure that the commentary reflects this, or else include an exchange of notes with each negotiated treaty to clarify its intentions.

\subsection{Uganda and the OECD model}

Uganda is a more frequent participant in the OECD's annual tax treaties forum than at the UN. Unlike the UN committee session, however, this is not generally a meeting at which decisions are taken about the treaty model: that happens at meetings of Working Party 1 and

Observation at UN committee annual sessions, 2013 and 2014

Attendance lists on file with the authors.

Interview with Finance Ministry officials, Kampala, September 2014. 
the Committee on Fiscal Affairs, which Uganda is not entitled to attend. Non-members are, however, able to enter formal observations on the OECD model treaty and its commentary, and many developing countries do. Currently, Ivory Coast, Gabon and the Democratic Republic of Congo are the only sub-Saharan states to have entered observations on the OECD model (Vega and Rudyk 2011).

Uganda has accepted OECD model clauses in many instances, but it has not entered any observations on the OECD model treaty. This means it may find itself bound in any treaty disputes by the interpretation of the treaty as articulated by OECD members. It also means that when negotiating partners bring the OECD model to the table, Uganda cannot point to an internationally-recognised articulation of its own response to that model.

Perhaps more importantly, by not recording any observations Uganda contributes to a tacit acceptance of the OECD model provisions, rather than supporting an emerging developing country position in opposition to more residence-based provisions that would strengthen developing countries' hands. For example, in 2010 the OECD made changes to article 7 of the model convention that substantially changed the balance of taxing rights from the operating countries of multinationals to their head office countries. Objections to this change were registered on behalf of Argentina, Azerbaijan, Brazil, Bulgaria, Colombia, Hong Kong, Indonesia, Latvia, Malaysia, Romania, Russia, Serbia, Singapore, South Africa and Thailand (OECD 2014c). This declared opposition is surely useful for developing countries wishing to prevent the inclusion of the new OECD provision in a treaty.

\subsection{Uganda and the EAC model}

In contrast to the OECD and UN models, Ugandan government officials indicated that they have participated actively in the formulation of the EAC model treaty for negotiations with third countries (Annex Table 4 shows a summary of the EAC treaty's provisions). Uganda's influence can be seen in the inclusion of a general limitation of benefits clause, which is similar to, but clearer than, that in Uganda's own legislation. Another strength of the EAC model is the inclusion of a management fees article with a 10 per cent withholding tax.

In other areas, the EAC model treaty would permit less taxation by Uganda of inward investment than one based on the UN model. It has a weaker definition of permanent establishment (e.g. delivery locations are excluded from the definition), and it lacks the UN paragraph 13(5) permitting source country taxation of capital gains from the sale of general shares. It also uses the weaker OECD definition of a property-rich company in paragraph 13(4), which can be avoided through the use of a partnership or trust.

In its quantitative articles, the EAC model makes the mistake of starting from a position that should be a final compromise, rather than the basis for opening negotiations. Perhaps most significantly, it begins with a six-month threshold for a permanent establishment for construction projects and services, despite an awareness in Uganda that many projects might fall below this threshold. It also specifies maximum withholding tax rates of 7.5 per cent on shares where the recipient owns more than 50 per cent of the company paying shares, well below the rate in most of Uganda's treaties. Withholding taxes on interest and royalty payments are set at 15 per cent, the same as Uganda's domestic law, but reduced to 10 per cent for related parties, a concession that surely should only be made, if at all, during negotiations in exchange for a benefit. The rate on management fees could also have been set at 15 per cent in the model.

Finally, the EAC model includes a most favoured nation (MFN) clause in its withholding tax articles. This is in article 14: 
If after the signature of this Agreement under any Convention or Agreement between a Contracting State and a third State, the Contracting State should limit its taxation at source on management or professional fees to a rate lower or a scope more restricted than the rate or scope provided for in this Agreement on the said items of income, then as from the date on which the relevant Contracting State Convention or Agreement enters into force the same rate or scope as provided for in that Convention or Agreement on the said items of income shall also apply under this Convention.

An MFN clause can strengthen a country's position in subsequent negotiations, because both sides appreciate the costs of agreeing to a lower rate. But, once triggered, those costs can be significant. A particular problem with this clause is that it is bilateral: in a treaty with a developed country, it could be triggered by that developed country concluding a subsequent agreement with lower withholding tax, even though any benefits from the resulting lower rate would overwhelmingly accrue to the developed country.

Such an incident occurred with the April 2003 Venezuela-Spain treaty. In May 2006, the bilateral MFN clause in its interest article was triggered through a kind of domino effect: Estonia and The Netherlands signed a treaty granting exclusive source taxation rights over interest: this activated the MFN clause in the September 2003 Spain-Estonia treaty, which in turn activated the MFN clause in the Venezuela-Spain treaty. As a result, 'Venezuela's treaty with Spain has undoubtedly become the most favorable tax treaty executed by Venezuela to date' (Escobar 2006). An MFN clause, just like a six-month PE definition, a 7.5 or 10 per cent WHT, and numerous smaller UN provisions that have not been carried across into the EAC model, ${ }^{48}$ should not be conceded in a model. It should be kept in reserve for treaty negotiations, only to be given up, if at all, in return for something else.

\subsection{Uganda and the COMESA model}

Documentation from the Common Market of Eastern and Southern Africa (COMESA) model treaty project indicates that Uganda was one of the few members of the group not to attend meetings at which this model was developed. ${ }^{49}$ In fact, it appears that URA officials did participate in the project at some point, but not the Ministry of Finance. ${ }^{50}$ Like the EAC model, the COMESA model has some strengths in comparison to the UN model, but its protection of source taxing rights is weaker than both the EAC and UN models. For example, its PE definition omits both delivery units and dependent agents maintaining stock; it also follows the less-expansive OECD definition of royalties. The model does not specify withholding tax rates, which may be preferable to the compromise rates specified in the EAC model, but is less beneficial than higher rates would be. Unlike the EAC model, it does not include an article on technical service fees.

There are two main advantages to the COMESA model. The first is the inclusion of antitreaty shopping provisions. Main purpose tests, which disqualify taxpayers from the lower rates if the main purpose of the transaction is to benefit from those lower rates, are included in some of the withholding tax articles, to complement the 'beneficial owner' and 'special relationship' anti-avoidance provisions. ${ }^{51}$ Second, member states can also enter reservations, which would allow Uganda to open its negotiations from a stronger position than that in the COMESA model itself. Uganda has already entered some reservations,

\footnotetext{
48 For example: source taxation of shipping in article 8 of the UN model, which is probably less interesting for a landlocked country; inclusion of payments for the use of equipment within the definition of royalties; taxation of senior managers in article 16 of the UN model.

49 COMESA project documents, on file with the authors.

$50 \quad$ Interviews with URA and Finance Ministry officials, Kampala, September 2014.

$51 \quad$ Notably, Mauritius has entered a reservation on these articles.
} 
including one indicating that it prefers to include an article allowing it to impose a withholding tax on management fees.

\subsection{Uganda needs an ambitious new model treaty}

There is no current model treaty that it would be advisable for Uganda to use as an opening position in negotiations. It is not satisfactory to rely on any one of these models. Instead, Uganda should develop its own model, taking into account its domestic law, and cherry picking from the best of its existing treaties and from the EAC, COMESA, UN and OECD models. Provisions that seem of little importance to Uganda, such as on shipping, should be included, but could be given up as part of horse-trading during negotiations. Uganda should enter reservations on important provisions at COMESA and the OECD, and ensure that commentaries to the EAC and UN model reflect its views.

A Ugandan model could include, for example:

1. All elements of the UN model PE definition, with a 90-day or lower period for construction sites and service PEs, as provided in Ugandan law.

2. 15 per cent WHT rates across the board, including on technical service fees, as in Uganda's treaty with the UK and its domestic legislation, with main purpose tests for passive income as in the COMESA model.

3. All capital gains provisions from the UN model.

4. The Limitation of Benefits or Principal Purpose clause from the EAC model or the forthcoming new OECD provision.

5. Exchange of information and collection of taxes provisions from the UN and EAC models.

\section{A holistic approach to tax treaty policy}

Tax treaties do not operate in a vacuum. They are part of a network of foreign investment instruments intended to ensure that the interests of investors are protected. Like treaties, these other instruments sometimes also result in revenue loss because they restrict the host country's ability to tax. For this reason, any review of a country's tax treaty policy should involve an analysis of these additional layers of investment protection. Two examples of such instruments are foreign investment contracts (such as production sharing agreements and power purchasing agreements), and other international investment agreements (including bilateral investment treaties). Similarly, a review of Uganda's tax treaty policy needs to pay close attention to some of the shortcomings in its domestic legislation, as the latter is in effect the starting point for negotiations.

\subsection{Treaty gains may be eroded by tax incentives contained in foreign investment contracts, such as production sharing agreements}

There is no direct relationship between tax treaties and production sharing agreements (PSAs). However, the latter also often contain provisions on taxation, which sometimes result in loss of tax revenue. For example, in Tullow Uganda Limited and Tullow Operational Property Ltd. $v$ Uganda Revenue Authority TAT Application No. 4 of 2011, one of the issues was whether Tullow could rely on an exemption from tax that was contained in the PSA signed between the company and the Minister for Energy, on behalf of the Government of Uganda. Article 23.5 of the agreement read inter alia: 
The assignment or transfer of an interest under this Agreement and any related Exploration or Production License shall not be subject to any tax, fee, or other impost or fee levied on the assignor or assignee in respect thereof.

The Tax Appeals Tribunal agreed that the wording of Article 23.5 was such that it provided an exemption to the company from all taxes, including capital gains tax. However, it held that the Minister of Energy did not have the legal authority to grant tax exemptions, since article 152 of the Uganda Constitution requires tax exemptions to be reported to parliament. In the earlier case of Heritage Oil \& Gas Limited v Uganda Revenue Authority Civil Appeal No. 14 of 2011, Heritage contested the capital gains tax that the URA had assessed on it for the transfer of its petroleum licence to Tullow. Again in this case, the court held that the Income Tax Act required that the company pay capital gains tax on the transaction. The combined tax revenue from these two assessments totalled some $\$ 900$ million. These cases illustrate the undesirability for tax issues to be included in negotiations with foreign investors by ministries responsible for attracting foreign investment.

While the URA was successful in taxing capital gains in the above two instances, this has not always been the case. Parliamentary records indicate that previous licence transfers from Neptune Petroleum to Tower Resources, and three transfers by Hardman Resources and Energy Africa to Tullow Oil were made without attracting taxes. ${ }^{52}$ Part of URA's success in the Tullow and Heritage cases may thus be attributed to heated debates in parliament in 2011, where MPs complained about the failure of government to tax capital gains in previous licence transfers. ${ }^{53}$

In addition to the tax-specific exemptions contained in PSAs, such as that concluded between Tullow and the Government of Uganda, PSAs often contain stabilisation clauses which have the effect of freezing domestic laws in as far as those laws apply to the transactions of the investor in question. Similarly, these agreements may contain economic equilibrium clauses which too frequently demand (prohibitive) compensation in the event of a government making legal changes that negatively impact on an investor's economic standing. It has been reported, for example, that the PSA concluded between the Government of Uganda and Heritage Oil \& Gas Limited had a clause to the effect that, "if there is any change, or series of changes, in the laws or regulations of Uganda which materially reduces the economic benefits of the company, the government must make substantial economic compensation' (Haywood 2010). The 1970s and 1980s witnessed numerous debates on the legality of stabilisation and economic equilibrium clauses. However, it appears to be now widely accepted in international law that these clauses are legally binding (Cotula 2007).

That Uganda's jurisprudence so far on PSAs and taxation has favoured the taxation of capital gains and reinforced the sovereignty of the state in as far as tax issues are concerned is a good precedent. However, these agreements have raised a red flag on the potential dangers in negotiation of foreign investment contracts.

\subsection{Interaction between BITs and the loss of domestic tax revenue}

Bilateral Investment Treaties (BITs), while not specific to taxation, may contain provisions that have a bearing on a country's ability to tax. Uganda has signed fifteen BITs, but only seven of these are in force (UNCTAD 2015). Of particular interest for our purposes is the BIT that Uganda concluded with the Netherlands, which came into force in January 2003. Article 4 thereof explicitly includes taxation matters within the treaty's effects:

The Republic of Uganda, Official Report of Debates of Parliament (Hansard) $9^{\text {th }}$ Parliament (10 October 2011) at 22-25. lbid. 
With respect to taxes, fees, charges and to fiscal deductions and exemptions, each Contracting Party shall accord to investors of the other Contracting Party who are engaged in any economic activity in its territory, treatment not less favourable than that accorded to its own investors or to those of any third State who are in the same circumstances, whichever is more favourable to the investors concerned. For this purpose, however, there shall not be taken into account any special fiscal advantages accorded by that Party:

(a) under an agreement for the avoidance of double taxation; or

(b) by virtue of its participation in a customs union, economic union or similar institution; or

(c) on the basis of reciprocity with a third State.

It is noteworthy that this provision expressly excludes the application of the "national treatment' and MFN clause to tax treaties. Even then, it still requires that investors from the Netherlands benefit from the most favourable tax clauses (including deductions and exemptions) that are accorded to any other group of investors under other arrangements that Uganda may enter into. We have already pointed out the risks associated with MFN clauses in Section 4.3. While other BITs in force in Uganda contain national and MFN treatment clauses, those agreements differ from the Dutch treaty in that they expressly provide that the clause does not apply to tax matters. Some of the BITs that Uganda has signed have expressly stated that the agreements will not apply to tax matters. For example, the agreement with China, while not yet in force, expressly provides in Article 3 that the Agreement shall not apply to matters of taxation in the territory of either Contracting Party'. The advantage with such a provision is that it ensures that general issues dealing with investment are handled by the Ministry of Trade and Industry, while the more specific and technical issues of taxation are handled by the MoFPED.

The Uganda-Netherlands BIT, coupled with the DTA signed between the two countries, creates more opportunities for reducing Uganda's taxing rights. This is made worse by the fact that the BIT is to remain effective for an initial period of fifteen years, meaning Uganda cannot exercise the option to terminate until six months before the expiry date (2018). If the agreement is not terminated at this point, the next opportunity for either contracting state to terminate the agreement will not be until 2028.

BITs pose another risk to taxation. They commonly include provisions allowing foreign investors recourse to external arbitration, which may result in the award of huge monetary compensation. It has been observed elsewhere, for example, that in the famous dispute between Vodafone International Holdings BV (the company) and the Government of India, the company opted to use the dispute resolution mechanism under a BIT instead of seeking to invoke the mutual agreement procedures in the DTA (Choudhury and Owens 2014).

\subsection{In some places, Uganda's domestic law is weaker than international model treaties and existing tax treaties}

There are instances where the Income Tax Act is weaker than international model treaties generally, and the tax treaties concluded by Uganda in particular. The first disadvantage of this is that if domestic laws play some role in guiding treaty negotiations - and we assume that they play at least some role - then a weak domestic law puts Uganda in a poor bargaining position from the onset. A second concern is that, as tax treaties cannot create a tax obligation where none exists in domestic law, there is little point in Uganda negotiating a better deal unless its own laws are revised. Such weaknesses include, for example, the definition of a Permanent Establishment (PE). As we noted earlier, withholding taxes may often be preferable to taxing net profits of a permanent establishment, but Uganda's tax policy officials also believe that obtaining a low PE threshold in their treaties is important to ensure that they can tax foreign companies operating in Uganda fairly. 
But Uganda's domestic law is closely based on tax treaty definitions of permanent establishment. Uganda's Income Tax (Transfer Pricing) Regulations, 2011, define a branch, a taxable entity, to mean:

a) a permanent establishment, in the case of a treaty signed between Uganda and another country; or

b) the definition found in Section 78 of the Income Tax Act.

Section 78 defines a branch to mean 'a place where a person carries on business,' and includes -

(i) a place where a person is carrying on business through an agent, other than a general agent of independent status acting in the ordinary course of business as such;

(ii) a place where a person has, is using or is installing substantial equipment or substantial machinery for ninety days or more; or

(iii) a place where a person is engaged in a construction, assembly, or installation project for ninety days or more, including a place where a person is conducting supervisory activities in relation to such a project;'

This domestic definition appears to be based on the PE concept in model tax treaties, but compared with the laundry list that the model treaties on what constitutes a PE, Uganda's domestic definition is actually much narrower. While its statutory definition of a branch provides for a shorter period (90 days) for when an establishment can be assessed on its business income than the PE concept in the UN model and most of its own treaties (6 months/183 days) and the OECD (365 days), the fact that many other structures and activities that might fall under the purview of the treaty definition are excluded leaves a lot to be desired. An argument could be made that these other activities would in any event be covered under Section 79 (s) of the Income Tax Act, which is to the effect that income is deemed to be sourced in Uganda if it is 'attributable to any other activity which occurs in Uganda, including an activity conducted through a branch in Uganda'. However, the fact that the sub-section refers to a branch leads us back to the three categories of branch identified under Section 78. Possibly the most effective way to safeguard Uganda's taxing rights would be to leave the domestic law definition of branch wide in scope, rather than modelling it on the tax treaty permanent establishment provision at all.

\section{Conclusion and recommendations}

None of the reasons articulated by the government of Uganda in the past or present for concluding tax treaties seem to hold up in the current context. Provisions for tax sparing are largely unnecessary and possibly undesirable. Double tax relief can be obtained unilaterally. ${ }^{54}$ Mutual assistance, clearly a priority for the URA, is not always delivered by Uganda's current treaties, and in any event would be more comprehensive and effective when obtained through multilateral agreements.

Meanwhile, none of Uganda's treaties meet the standards set out in the UN model. At present there is a major problem in the form of treaty shopping through the Dutch treaty, which should be the top priority for renegotiation. However, renegotiating priorities should not stop at treaty shopping. The weak permanent establishment provisions in Uganda's treaties

A possible exception to this is within the EAC, where the absence of double taxation relief may be a hindrance for Kenyan investors until the new EAC multilateral tax treaty is ratified. 
mean there is a pool of inward investment of indeterminate size that Uganda cannot currently tax. Perhaps more significant is the major lack of source taxing rights over capital gains made by inward investors. The high-profile Zain and Heritage court cases indicate that Uganda wishes to tax capital gains when business interests in Uganda are sold on by overseas investors, but Uganda's treaties are not fit for this purpose.

Re-evaluating its current treaties against existing standards may not be enough, however. If Uganda decides that tax treaties are desirable, it needs a stronger model than those currently available to it. This should present a best-possible scenario, so that the eventual outcome of negotiations is closer to the reasonable compromise position embodied by the UN model. The EAC and COMESA models contain some ambitious elements, but overall they are no stronger as opening positions than the UN model. Uganda also needs more robust domestic laws to bolster its negotiating position and ensure that it can interpret its treaties expansively, and to ensure that other investment promotion instruments do not further weaken its taxing rights.

Furthermore, Uganda should ask itself not just, 'Why sign new treaties?' and 'How should existing treaties be renegotiated?', but also 'Why keep existing treaties?' Path dependence may well be an important answer. Investor surveys do reveal that Uganda's stable political and economic regime is one of its most important assets in attracting investment (Uganda Bureau of Statistics 2012). There may therefore be concern that cancelling tax treaties might create what a tax adviser described as negative PR. Alternatively, a reputation for stability may cushion Uganda against fears that treaty cancellations are a prelude to a dramatic shift towards discriminatory or unfair taxation.

A suggested course of action for Uganda's review could include the following steps:

1. Identify the areas where tax treaties and domestic legislation leave it most vulnerable to revenue loss. This includes PE definition (treaty and domestic), treaty shopping (treaty and domestic), withholding taxes (treaty) and capital gains (treaty and PSAs).

2. Incorporate an assessment of tax foregone due to tax treaties into the government's annual statement of tax expenditure.

3. Formulate an ambitious Ugandan model by applying a 'best available' approach to existing models (EAC, COMESA, UN), current treaties and domestic legislation, none of which are currently adequate. This might include:
a. All elements of the UN model PE definition, with a 90-day period for construction sites and service PEs as per Ugandan law.
b. 15 per cent withholding tax rates across the board, including on technical service fees, as per Uganda's treaty with the UK and its domestic legislation, with main purpose tests for passive income as per the COMESA model.
c. All capital gains provisions from the UN model.
d. The Limitation of Benefits clause from the EAC model or the forthcoming new OECD provision.
e. Exchange of information and collection of taxes provisions from the UN and EAC models.

4. Identify red lines within the Ugandan model. This should certainly include items $\mathrm{c}, \mathrm{d}$ and e from the above list.

5. Based on investment and remittance data, request renegotiation of treaties that have the greatest actual (or potential in terms of capital gains) cost. At first sight, this appears to be the treaties with the Netherlands, Mauritius, UK and China. These renegotiations should be conducted on the basis of an improved distribution of taxing rights in Uganda's favour, not a balanced negotiation.

6. Cancel these high-impact treaties if the red lines cannot be obtained. 
7. Ensure that future updates to provisions of model treaties that Uganda uses, or to their commentaries and reservations/observations, reflect the positions set out in this new Ugandan model.

8. As part of this review, ensure consistency between tax treaty objectives and the Income Tax Act, tax incentives, foreign investment contracts and Bilateral Investment Treaties. 


\section{Annex: Additional tables}

Annex Table 1 Some recent tax treaty cancellations

\begin{tabular}{|l|l|l|l|}
\hline $\begin{array}{l}\text { Terminating } \\
\text { country }\end{array}$ & Partner country & $\begin{array}{l}\text { Year } \\
\text { terminated }\end{array}$ & Reason given \\
\hline Germany & Brazil & 2005 & $\begin{array}{l}\text { Non-standard transfer pricing rules in Brazil; new Brazilian taxes } \\
\text { not included; no need for matching credits (Haddad et al. 2005). }\end{array}$ \\
\hline Indonesia & Mauritius & 2006 & $\begin{array}{l}\text { 'There was an abuse that was inflicting a loss upon Indonesia' (SG } \\
\text { Financial Services n.d.). }\end{array}$ \\
\hline Argentina & Austria & 2008 & Suggested to be due to treaty shopping (Sovereign Group 2008). \\
\hline Rwanda & Mauritius & 2012 & Appears to have been part of renegotiation strategy \\
\hline Mongolia & Luxembourg & 2012 & $\begin{array}{l}\text { Treaty shopping by mining companies; slow response to request to } \\
\text { renegotiate (Government of Mongolia 2012) }\end{array}$ \\
\hline Mongolia & Netherlands & 2012 & $\begin{array}{l}\text { Treaty shopping by mining companies; refusal to meet } \\
\text { renegotiation terms (Government of Mongolia 2012) }\end{array}$ \\
\hline Argentina & Chile & 2012 & Appears to have been part of renegotiation strategy \\
\hline Argentina & Spain & 2012 & Appears to have been part of renegotiation strategy \\
\hline Argentina & Switzerland & 2012 & Appears to have been part of renegotiation strategy \\
\hline Malawi & Netherlands & 2013 & \\
\hline
\end{tabular}




\begin{tabular}{|c|c|c|c|c|c|c|c|c|c|c|c|}
\hline Article & Description & 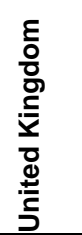 & 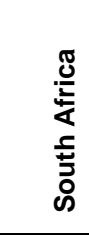 & i़ &  & 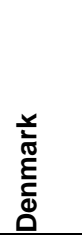 &  & 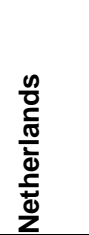 & $\stackrel{\frac{\pi}{\sigma}}{\underline{\underline{c}}}$ & 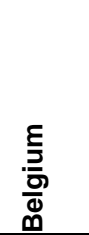 & $\frac{\pi}{\frac{5}{\delta}}$ \\
\hline & Year signed & 1992 & 1997 & 1999 & 2000 & 2000 & 2003 & 2004 & 2004 & 2007 & $2012^{55}$ \\
\hline $5(3)(a)$ & $\begin{array}{l}\text { Construction PE } \\
\text { (months) }\end{array}$ & 6 & 6 & 6 & 6 & 6 & 6 & 6 & 6 & 6 & 6 \\
\hline $5(3)(a)$ & Supervisory activities & 0 & $u$ & u & 0 & $U$ & $U$ & $u$ & $U$ & $u$ & $u$ \\
\hline $5(3)(b)$ & Service PE (months) & 0 & 0 & 0 & 6 & 0 & 4 & 4 & 0 & 0 & 6 \\
\hline $5(4)(a)$ & PE exclusion - delivery & 0 & U & $u$ & 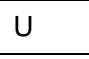 & 0 & $\mathrm{U}$ & $u$ & 0 & $u$ & $u$ \\
\hline $5(4)(b)$ & $\begin{array}{l}\text { PE exclusion - } \\
\text { delivery }\end{array}$ & O & $u$ & $u$ & U & 0 & $u$ & U & U & $u$ & $u$ \\
\hline $5(5)(b)$ & $\begin{array}{l}\text { Dependent agent - } \\
\text { stock }\end{array}$ & O & 0 & 0 & 0 & 0 & u & 0 & U & 0 & o \\
\hline $5(6)$ & Insurance PE & 0 & 0 & 0 & 0 & 0 & 0 & 0 & 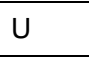 & $\mathrm{U}$ & 0 \\
\hline & Oil exploration PE & NA & NA & NA & NA & 30 & NA & 30 & NA & NA & NA \\
\hline $\begin{array}{l}7(1) \\
(\mathrm{b} \& \mathrm{c})\end{array}$ & $\begin{array}{l}\text { Limited force of } \\
\text { attraction }\end{array}$ & 0 & 0 & O & O & 0 & 0 & O & 0 & 0 & O \\
\hline $7(3)$ & $\begin{array}{l}\text { Deductions } \\
\text { clarification }\end{array}$ & O & $u$ & U & U & U & U & U & 0 & U & 0 \\
\hline $8(2)$ & $\begin{array}{l}\text { Shipping and air } \\
\text { transport }\end{array}$ & o & O & O & o & O & o & O & O & 0 & o \\
\hline $9(3)$ & Deductions - penalty & 0 & 0 & 0 & $u$ & $u$ & $u$ & $u$ & 0 & $u$ & 0 \\
\hline 10 & $\begin{array}{l}\text { WHT on FDI dividend } \\
(\%)\end{array}$ & 15 & 10 & 10 & 15 & 10 & 10 & $0 / 15$ & 10 & 5 & 7.5 \\
\hline 10 & FDI threshold (\%) & NA & 25 & 25 & NA & 25 & NA & 50 & NA & 10 & NA \\
\hline 10 & $\begin{array}{l}\text { WHT on portfolio } \\
\text { dividend (\%) }\end{array}$ & 15 & 15 & 15 & 15 & 15 & 10 & $5 / 15$ & 10 & 15 & 7.5 \\
\hline 11 & WHT on interest (\%) & 15 & 10 & 10 & 15 & 10 & 10 & 10 & 10 & 10 & 10 \\
\hline 12 & WHT on royalties (\%) & 15 & 10 & 10 & 10 & 10 & 10 & 10 & 10 & 10 & 10 \\
\hline 12 & Royalty definition - TV & $\mathrm{U}$ & $u$ & $u$ & $u$ & 0 & $\mathrm{U}$ & 0 & U & $u$ & $u$ \\
\hline 12 & $\begin{array}{l}\text { Royalty definition - } \\
\text { equipment }\end{array}$ & U & 0 & O & U & U & U & O & U & 0 & u \\
\hline $12 a$ & $\begin{array}{l}\text { WHT on management } \\
\text { fees }(\%)\end{array}$ & 15 & 10 & 10 & 10 & 10 & 10 & NA & 10 & 10 & NA \\
\hline $13(4)$ & $\begin{array}{l}\text { Capital gains - } \\
\text { property rich }\end{array}$ & O- & O- & O- & O- & O- & O- & O- & 0 & O- & 0 \\
\hline $13(5)$ & $\begin{array}{l}\text { Capital gains - other } \\
\text { shares }\end{array}$ & O & 0 & U & O & 0 & 0 & O & U & 0 & O \\
\hline 16 & $\begin{array}{l}\text { Director's fees - } \\
\text { include senior } \\
\text { managers }\end{array}$ & 0 & 0 & 0 & 0 & 0 & 0 & 0 & 0 & $u$ & 0 \\
\hline 18 & $\begin{array}{l}\text { Pensions - shared } \\
\text { taxing right }\end{array}$ & O & 0 & O & O & $U_{+}$ & 0 & $U_{+}$ & 0 & $\mathrm{U}_{+}$ & O \\
\hline 18 & $\begin{array}{l}\text { Pensions - social } \\
\text { security }\end{array}$ & 0 & 0 & 0 & 0 & $u$ & $\mathrm{O}$ & U & $\mathrm{O}$ & $u$ & $u$ \\
\hline $21(3)$ & Other income & 0 & $\mathrm{U}$ & 0 & 0 & $U$ & 0 & 0 & 0 & $\mathrm{U}$ & 0 \\
\hline 26 & Information exchange & Yes & Yes & Yes & Yes & Yes & Yes & Yes & Yes & Yes & Yes \\
\hline 27 & Collection of taxes & No & Yes & Yes & Yes & No & No & Yes & Yes & Yes & No \\
\hline
\end{tabular}

O: OECD provision

$\mathrm{U}$ : UN provision

$U_{+}$: more generous UN provision where there is an option.

$55 \quad$ While IBFD (2014) states that this treaty was signed in 2012, MofPED officials claim it has not yet been signed. 
Annex Table 3 Selected provisions of sub-Saharan Africa countries' treaties with China, Mauritius and the Netherlands (all figures \%)

\begin{tabular}{|l|r|r|r|r|r|}
\hline China & \multicolumn{1}{l|}{ Nigeria } & \multicolumn{1}{l|}{ Ethiopia } & \multicolumn{1}{l|}{ Zambia } & \multicolumn{1}{l|}{ Botswana } & \multicolumn{1}{l|}{ Uganda } \\
\hline & $\mathbf{2 0 0 2}$ & $\mathbf{2 0 0 9}$ & $\mathbf{2 0 1 0}$ & $\mathbf{2 0 1 2}$ & \\
\hline Construction PE & 6 & 6 & 9 & 12 & 6 \\
\hline Supervisory activities & Yes & Yes & Yes & Yes & Yes \\
\hline Services PE & No & No & 6 & 6 & 6 \\
\hline Dividends & 7.5 & 5 & 5 & 5 & 7.5 \\
\hline Interest & 7.5 & 7 & 10 & 7.5 & 10 \\
\hline Royalties & 7.5 & 5 & 5 & 5 & 10 \\
\hline Mgmt fees & Exempt & Exempt & Exempt & Exempt & Exempt \\
\hline CGT Property rich & No & Yes & Yes & Yes & Yes \\
\hline CGT shares & No & No & No & No & No \\
\hline
\end{tabular}

\begin{tabular}{|c|c|c|c|c|c|c|c|c|c|c|c|c|}
\hline Mauritius & 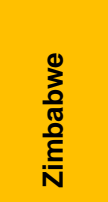 & 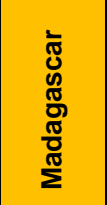 & 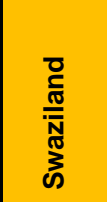 & 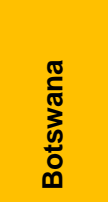 & $\begin{array}{l}\frac{\pi}{0} \\
\frac{0}{\underline{E}} \\
\frac{\pi}{Z}\end{array}$ & 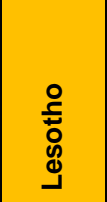 &  & 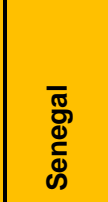 & $\begin{array}{l}\frac{\pi}{0} \\
\frac{\pi}{5} \\
\frac{\pi}{5}\end{array}$ & $\begin{array}{l}\frac{\pi}{0} \\
\frac{0}{E} \\
\text { N } \\
\text { N }\end{array}$ & $\begin{array}{l}\stackrel{\pi}{\grave{\Phi}} \\
\stackrel{\Phi}{\Phi}\end{array}$ & 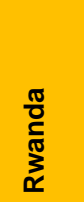 \\
\hline & 1992 & 1994 & 1994 & 1995 & 1995 & 1997 & 1997 & 2002 & 2003 & 2011 & 2012 & 2013 \\
\hline $\begin{array}{l}\text { Construction } \\
\text { PE }\end{array}$ & 6 & 6 & 6 & 6 & 6 & 6 & 6 & 9 & 6 & 9 & 12 & 6 \\
\hline $\begin{array}{l}\text { Supervisory } \\
\text { activities }\end{array}$ & Yes & Yes & Yes & Yes & Yes & Yes & Yes & Yes & Yes & Yes & Yes & Yes \\
\hline Services PE & No & No & 6 & 6 & 6 & 6 & 6 & 9 & 4 & No & 6 & 6 \\
\hline Dividends & 10 & 5 & 7.5 & 5 & 5 & 10 & 8 & Exempt & 10 & 5 & 5 & 10 \\
\hline Interest & 10 & 10 & 5 & 12 & 10 & 10 & 8 & Exempt & 10 & 10 & 10 & 10 \\
\hline Royalties & 15 & 5 & 7.5 & 12.5 & 5 & 10 & 5 & Exempt & 10 & 5 & 10 & 10 \\
\hline Mgmt fees & Exempt & Exempt & Exempt & Exempt & Exempt & Exempt & Exempt & Exempt & 10 & Exempt & Exempt & 12 \\
\hline $\begin{array}{l}\text { CGT Property } \\
\text { rich }\end{array}$ & Yes & No & No & No & No & Yes* & No & No & No & NA & No & No \\
\hline CGT shares & No & No & No & No & No & No & No & No & No & NA & No & No \\
\hline
\end{tabular}

\begin{tabular}{|l|r|r|r|r|r|r|}
\hline Netherlands & Zambia & Zimbabwe & \multicolumn{1}{l|}{ Nigeria } & \multicolumn{1}{l|}{ Uganda } & \multicolumn{1}{l|}{ Ghana } & Ethiopia \\
\hline & 1977 & $\mathbf{1 9 8 9}$ & $\mathbf{1 9 9 1}$ & $\mathbf{2 0 0 4}$ & $\mathbf{2 0 0 8}$ & $\mathbf{2 0 1 2}$ \\
\hline Construction PE & 6 & 6 & 3 & 6 & 9 & 6 \\
\hline Supervisory activities & Yes & No & Yes & Yes & Yes & No \\
\hline Services PE & No & No & 3 & 4 & No & No \\
\hline Dividends & 5 & 10 & 12.5 & $0 / 15$ & 5 & 5 \\
\hline Interest & 10 & 10 & 12.5 & 10 & 8 & 5 \\
\hline Royalties & 10 & 10 & 12.5 & 10 & 8 & 5 \\
\hline Mgmt fees & Exempt & Exempt & Exempt & Exempt & 8 & Exempt \\
\hline CGT Property rich & No & No & No & No & Yes^ & Yes* \\
\hline CGT shares & No & Yes & No & No & No & No \\
\hline
\end{tabular}


Annex Table 4 Comparison of provisions in EAC and COMESA model treaties (all figures \%)

Red indicates provision is worse (less source-based) than the UN model

Green indicates provision is better than the UN model

\begin{tabular}{|c|c|c|c|}
\hline $\begin{array}{l}\text { UN model } \\
\text { reference }\end{array}$ & Provision & EAC & COMESA \\
\hline $5(3)(a)$ & Construction PE (months) & 6 & Unspecified \\
\hline $5(3)(a)$ & Supervisory activities & Yes & Yes \\
\hline $5(3)(b)$ & Service PE (months) & 6 & Unspecified \\
\hline $5(4)(a)$ & PE exclusion - delivery excluded & Yes & Yes \\
\hline $5(4)(b)$ & PE exclusion - delivery excluded & Yes & Yes \\
\hline $5(5)(b)$ & Dependent agent - stock included & Yes & No \\
\hline $5(6)$ & Insurance PE & Yes & Yes \\
\hline $7(1)(b \& c)$ & Limited force of attraction & Yes & No \\
\hline $7(3)$ & Deductions clarification & Yes & Yes \\
\hline $8(2)$ & Shipping and air transport & No & No \\
\hline $9(3)$ & Deductions - penalty & Yes & No \\
\hline 10 & WHT on FDI dividend (\%) & 7.5 & Unspecified \\
\hline 10 & FDI threshold (\%) & 50 & Unspecified \\
\hline 10 & WHT on portfolio dividend (\%) & 15 & Unspecified \\
\hline 11 & WHT on interest (\%) & 10 OR 15 & Unspecified $^{\wedge}$ \\
\hline 12 & WHT on royalties (\%) & 10 OR 15 & Unspecified^ $^{\wedge}$ \\
\hline 12 & Royalty definition - TV & Yes & No \\
\hline 12 & Royalty definition - equipment & No & No \\
\hline $12 \mathrm{a}$ & WHT on management fees & 10 & $\mathrm{No}^{*}$ \\
\hline $13(4)$ & Capital gains - property rich & No & No \\
\hline $13(5)$ & Capital gains - other shares & No & No \\
\hline 16 & Director's fees - include senior managers & No & No \\
\hline 18 & Pensions - shared taxing right & Yes & Yes \\
\hline 18 & Pensions - social security & Yes & Yes \\
\hline \multirow[t]{2}{*}{$21(3)$} & Other income & Yes & Yes \\
\hline & General limitation of benefits & Yes & No \\
\hline 26 & Exchange of information & Yes & Yes \\
\hline 27 & Collection of taxes & Yes & Yes \\
\hline
\end{tabular}

$\wedge$ Includes main purpose test.

* Burundi, Malawi, Rwanda, Swaziland, Uganda and Zambia reserve the right to include a separate article concerning technical service fees, similar to article 12 . 


\section{References}

Aukonobera, P. (2012) 'Uganda', in M. Lang, P. Pistone and J. Schuch (eds), The impact of the OECD and UN model conventions on bilateral tax treaties, Cambridge University Press

Avi-Yonah, R. (2009) ‘Double Tax Treaties: An Introduction', in K. Sauvant and L. Sachs (eds), The Effect of Treaties on Foreign Direct Investment, New York: Oxford University Press

_ (2007) International Tax as International Law, New York: Cambridge University Press

Baistrocchi, E. (2008) 'The use and interpretation of tax treaties in the emerging world: theory and implications', British Tax Review 28(4): 352

Barthel, F. and Neumayer, E. (2012) 'Competing for Scarce Foreign Capital: Spatial Dependence in the Diffusion of Double Taxation Treaties', International Studies Quarterly 56(4): 645-660

— Busse, M. and Neumayer, E. (2009) 'The Impact of Double Taxation Treaties on Foreign Direct Investment: Evidence From Large Dyadic Panel Data', Contemporary Economic Policy 28(3): 366-377

Becker, J. and Fuest, C. (2012) 'The Nexus of Corporate Income Taxation and Multinational Activity', FinanzArchiv: Public Finance Analysis 68(3): 231-251

Blonigen, B, Oldenski, L. and Sly, N. (2014) 'The Differential Effects of Bilateral Tax Treaties', American Economic Journal: Economic Policy 6: 1-18

Choudhury, H. and Owens, J. (2014) Bilateral Investment Treaties and Bilateral Tax Treaties, International Tax and Investment Center Issue <http://www.iticnet.org/images/Bilateral\%20Investment\%20Treaties\%20and\%20Bilater al\%20Tax\%20Treaties.pdf>

Christians, A. (2005) 'Tax Treaties for Investment and Aid to Sub-Saharan Africa: A Case Study', Brooklyn Law Review 71(2): 639-700

Cooper, G. (2014) 'Preventing tax treaty abuse', in Handbook on Selected Issues in Protecting the Tax Base of Developing Countries, New York: United Nations

Cotula, L. (2007) Briefing 4: Foreign Investment Contracts, International Institute for Environment and Development, available from $<$ http://pubs.iied.org/pdfs/17015IIED.pdf>

Cui, W. (2014) 'Taxation of non-residents' capital gains', in Handbook on Selected Issues in Protecting the Tax Base of Developing Countries, New York: United Nations

Dagan, T. (2000) 'The Tax Treaties Myth', New York University Journal of International Law and Politics 32: 939

Dauer, V. and Krever, R. (2012) Choosing between the UN and OECD Tax Policy Models: an African Case Study, WU International Taxation Research Paper Series No 201416, universitat wien 
Davies, R., Norbäck, P. and Tekinoru, A. (2009) 'The effect of tax treaties on multinational firms: new evidence from microdata', The World Economy 32

Egger, P. and Merlo, V. (2011) 'Statutory Corporate Tax Rates and Double-Taxation Treaties as Determinants of Multinational Firm Activity', Finanzarchiv 67

Escobar, L. (2006) 'MFN Clause Activated in Spain-Venezuela Tax Treaty', Tax Notes International 44(11): 846-847

Government of Mongolia (2012) Proposals and explanations for revocation of double taxation agreement, available from <http://www.iltod.gov. $\mathrm{mn} / \mathrm{p}=2712>$

Haddad, G., Carramaschi, B., Schaflitzl, A. and Roschmann, C. (2005) 'Double Taxation Treaty Between Brazil and Germany', Linklater Taxation (34): 1-6

Haywood, K. (2010) 'Uganda: Oil Clause Binds Country on Legislation, Says Report', The Monitor, Kampala, 11 February 2010

Hearson, M. (2014) 'Time we scrutinised China's tax treaty practice, too', Tax, Development and International Relations, available from:

$<$ http://martinhearson.wordpress.com/2014/07/02/time-we-scrutinised-chinas-taxtreaty-practice-too/>

_ and Brooks, R. (2010) Calling Time: Why SABMiller should stop dodging taxes in Africa, London: ActionAid UK

IBFD (2016) IBFD Tax Research Platform, available from <http://online.ibfd.org/>

IMF (2014a) Spillovers on International Corporate Taxation, Washington DC: International Monetary Fund

— (2014b) Co-ordinated Direct Investment Survey 2012, available from $<$ http://cdis.imf.org/>

Irish C. (1974) 'International Double Taxation Agreements and Income Taxation At Source', International and Comparative Law Quarterly, 23(2): 292-316

Irish Ministry of Finance (2014) Public Consultation: Spillover Analysis - Possible Effects of the Irish Tax System on Developing Economies, Dublin

Jandhyala, S., Henisz, W. and Mansfield E. (2011) 'Three Waves of BITs: The Global Diffusion of Foreign Investment Policy', Journal of Conflict Resolution, 55(6): 10471073

Jones, J. (1999) 'Are tax treaties necessary?', Tax Law Review 53(1): 1-38

Kalinaki, D. (2014) 'Court gives URA nod to seek taxes on sale of Zain assets in Uganda', The East African, Nairobi, 13 September 2014

Kangave, J. (2009) 'The Dominant Voices in Double Taxation Agreements: A Critical Analysis of the "Dividend" Article in the Agreement between Uganda and the Netherlands', International Community Law Review 11(4): 387-407 
— Nakato, S, Waiswa, R. and Lumala Zzimbe, P. (2016) Boosting Revenue Collection through Taxing High Net Worth Individuals: The Case of Uganda. ICTD Working Paper 45, Brighton: International Centre for Tax and Development

Ladu, I. (2014) 'Govt suspends Double Taxation pacts', Daily Monitor, Kampala, 6 June

Lejour, A. (2014) The Foreign Investment Effects of Tax Treaties, CPB Discussion Paper 265

Li, J. (2012) 'The Great Fiscal Wall of China: Tax Treaties and Their Role in Defining and Defending China's Tax Base', Bulletin for International Taxation 66(9): 452-479

McGauran, K. (2013) Should the Netherlands sign tax treaties with developing countries?, SOMO, available from <http://somo.nl/publications-

en/Publication_3958/at_download/fullfile>

MTN Group Plc (2014) MTN Group Structure, available from:

$<$ https://www.mtn.com/mtngroup/about/pages/structure.aspx>, accessed 23 October 2014

Netherlands Ministry of Finance (2013) Government's response to the report from SEO Economics Amsterdam on Other Financial Institutions and the IBFD report on developing countries

OECD (2014a) Preventing the Granting of Treaty Benefits in Inappropriate Circumstances

- (2014b) Part 2 of a report to G20 Development Working Group on the Impact of BEPS in Low Income Countries, Paris: Organisation for Economic Co-operation and Development

- (2014c) Model Tax Convention on Income and on Capital, 2014 ed., Paris: Organisation for Economic Co-operation and Development

- (1998) Tax Sparing : a Reconsideration, Paris: Organisation for Economic Cooperation and Development

Picciotto, S. (1992) International business taxation: a study in the internationalization of business regulation, London: Weidenfeld and Nicolson

Pickering, A. (2013) Why Negotiate Tax Treaties, New York: United Nations

Poulsen, L. (2014) 'Bounded Rationality and the Diffusion of Modern Investment Treaties', International Studies Quarterly 58(1): 1-14

PWC (2013) Evolution of Territorial Tax Systems in the OECD

Quinones Cruz, N. (2012) 'Colombia', in M. Lang, P. Pistone, and J. Schuch (eds), The impact of the OECD and UN model conventions on bilateral tax treaties, Cambridge: Cambridge University Press

Rixen, T. and Schwarz, P. (2009) 'Bargaining over the Avoidance of Double Taxation: Evidence from German Tax Treaties', FinanzArchiv: Public Finance Analysis 65(4): 442-471 
Sauvant, K. and Sachs, L. (eds) (2009) The Effect of Treaties on Foreign Direct Investment, Oxford University Press

SEATINI and ActionAid Uganda (2014) Double Taxation Treaties in Uganda: Impact and Policy Implications

Self, H. (2014) Some treaty issues for Developing Countries, London: Queen Mary University guest lecture, 30 January

SG Financial Services (n.d.) Mauritius Double Tax treaties, available from $<\mathrm{http}: / /$ www.sgfinancialservices.net/tax_treaty>

Sovereign Group (2008) Austria publishes Argentina's denouncement of tax treaty, available from <http://www.sovereigngroup.com/offshore-news/sovereignnews/630/0/Austria+publishes+Argentina\%27s+denouncement+of+tax+treaty.html>

Thuronyi, V. (2010) 'Tax Treaties and Developing Countries', in M. Lang, P. Pistone, J. Schuch et al. (eds), Tax treaties: building bridges between law and economics, Amsterdam: IBFD

Tobin, J. and Rose-Ackerman, S. (2011) 'When BITs have some bite: The political-economic environment for bilateral investment treaties', Review of International Organizations $6(1): 1-32$

Uganda Bureau of Statistics (2012) Investor Survey Report 2012, Kampala

UNCTAD (2015) International Investment Agreements Navigator: Uganda, available from $<$ http://investmentpolicyhub.unctad.org/IIA/CountryBits/218\#iialnnerMenu>

United Nations (2014) Papers on Selected Topics in Negotiation of Tax Treaties for Developing Countries, New York: United Nations

_ (2013) Handbook on Administration of Double Tax Treaties for Developing Countries, New York: United Nations

- (2003) Manual for the Negotiation of Bilateral Tax Treaties between Developed and Developing Countries, New York: United Nations

Vega, A. and Rudyk, I. (2011) 'Explaining Reservations to the OECD Model Tax Convention: An Empirical Approach', Indret (4): 1-19

Weyzig, F. (2012) 'Tax treaty shopping: structural determinants of Foreign Direct Investment routed through the Netherlands', International Tax and Public Finance

— and van Dijk, M. (2007) Tax haven and development partner, Amsterdam

Wijnen, W. and de Goede, J. (2013) The UN Model in Practice 1997-2013, International Bureau of Fiscal Documentation

— - and Alessi, A. (2012) 'The Treatment of Services in Tax Treaties', Bulletin for International Taxation, 27-38

Yackee, J. (2005) 'Are BITs such a bright idea? Exploring the ideational basis of investment treaty enthusiasm', Journal of International Law and Policy 12(1): 195-224 


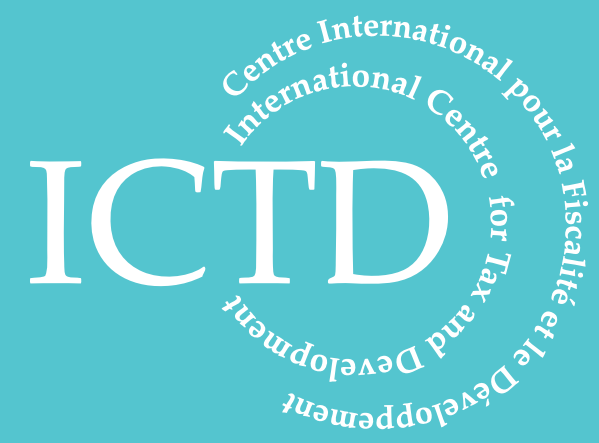

International Centre for Tax and Development at the Institute of Development Studies

Brighton BN1 9RE, UK

T: +44 (0) 1273606261

F: $+44(0) 1273621202$

E: info@ictd.ac

www.ictd.ac 